\title{
REVISITANDO AS ASCLEPIADOIDEAE (APOCYNACEAE) DA CADEIA DO ESPINHAÇO
}

\author{
ALESSANDRO RAPINI \\ Departamento de Botânica, Universidade Estadual de Feira de Santana, Av. Transnordestina s/n, Novo Horizonte, 44036-900, Feira de \\ Santana, Bahia, Brasil. e-mail: rapinibot@yahoo.com
}

\begin{abstract}
Revisiting the Asclepiadoideae (Apocynaceae) from the Espinhaço Range)]. A survey of the Asclepiadoideae (Apocynaceae) from the Espinhaço Range is presented. Based on the determinations of 3,615 collections, 133 species and 24 genera were recorded for this region; the most diverse genera are Ditassa (30 species), Oxypetalum (24), Minaria (19), Hemipogon (9), and Matelea (8). Within the Espinhaço Range, 108 species occur in Minas Gerais and 66 species occur in Bahia; 41 (ca. 30\%) of these species are found in both states. Fortytwo (ca. 30\%) species are endemic to the Espinhaço Range, which are mostly found in the Serra do Cipó and Diamantina Plateau, in Minas Gerais, and Chapada Diamantina, in Bahia. The sampling effort in Bahia is nearly half of that in Minas Gerais. As seen with Minas Gerais, this suggests that collecting more in Bahia will lead to the discovery of new taxa and to a better understanding of the distribution ranges of known species. In comparison with a survey published almost 10 years ago, for the Minas Gerais section of the Espinhaço Range, the classification of nearly $20 \%$ of the species has changed; most of these changes were based on phylogenetic studies. As a consequence, these studies about the Asclepiadoideae are revealing lineages that evolved predominantly in the Espinhaço Range, such as Minaria and Hemipogon. They also indicate that cladogenesis events might have been more frequent in the Espinhaço Range of Minas Gerais compared to the section in Bahia or, alternatively, extinctions events have been rarer in the Minas Gerais section. This pattern suggests that environmental factors are directly involved in the diversification of these plants along the Espinhaço Range and that comparative studies between the two sections of this range may reveal the principal causes associated with the rise of microendemics.
\end{abstract}

Resumo - [Revisitando as Asclepiadoideae (Apocynaceae) da Cadeia do Espinhaço]. É apresentado um levantamento das Asclepiadoideae (Apocynaceae) da Cadeia do Espinhaço. Com base na identificação de 3.615 registros, foram reconhecidos 133 espécies e 24 gêneros para a região; os gêneros mais diversos são Ditassa (30 espécies), Oxypetalum (24), Minaria (19), Hemipogon (9) e Matelea (8). Na Cadeia do Espinhaço, ocorrem 108 espécies em Minas Gerais e 66 na Bahia; 41 (ca. 30\%) dessas espécies são encontradas nos dois Estados. Quarenta e duas (ca. 30\%) espécies são endêmicas do Espinhaço; estando concentradas principalmente na Serra do Cipó e no Planalto de Diamantina, em Minas Gerais, e na Chapada Diamantina, na Bahia. O esforço de coleta na Bahia é quase a metade daquele em Minas Gerais. Como visto em Minas Gerais, isso sugere que o aumento de coletas na Bahia levará à descoberta de novos táxons e a uma melhor compreensão sobre a distribuição geográfica das espécies. Em comparação com o levantamento publicado há cerca de 10 anos para a porção mineira da Cadeia do Espinhaço, a classificação de praticamente $20 \%$ das espécies foi modificada, a maioria dessas mudanças baseada em estudos filogenéticos. Como conseqüência, esses estudos em Asclepiadoideae estão revelando linhagens que evoluíram predominantemente na Cadeia do Espinhaço, como Minaria e Hemipogon. Eles parecem indicar também que eventos de cladogênese parecem ter sido mais freqüentes no Espinhaço de Minas Gerais do que no da Bahia ou, alternativamente, eventos de extinção são mais raros na porção mineira. Este padrão sugere que fatores ambientais estão diretamente envolvidos na diversificação dessas plantas ao longo do Espinhaço e que estudos comparativos entre as duas porções dessa cadeia poderão indicar as principais causas relacionadas à origem de de espécies microendêmicas.

Key words: diversification, endemism, floristics, sampling effort, systematics.

\section{Introdução}

Com uma flora singular e extremamente diversificada, a Cadeia do Espinhaço continua atraindo a atenção de vários botânicos. Quase 10\% da flora brasileira está representada em suas serras e boa parte dessa diversidade encontrase confinada aos campos rupestres. Essa vegetação herbáceo-arbustiva sobre solos quártzicos, predominante em altitudes a partir de $900 \mathrm{~m}$, possui uma das maiores taxas de endemismos do país. Várias de suas espécies são raras, seja pela distribuição restrita, seja pela baixa densidade de indivíduos, e várias localidades são de difícil acesso, permanecendo subamostradas ou praticamente inexploradas. As novidades e descobertas para quem estuda essa flora são acontecimentos corriqueiros, levando a modificações e atualizações constantes dos dados (Rapini et al. 2008, e referências lá citadas). Essa situação é ainda mais marcante quando se procura tratar as informações taxonômicas dentro de uma perspectiva orientada pela sistemática filogenética, onde mudanças nas hipóteses de 
relações de parentesco acabam por influenciar diretamente a classificação dos táxons.

São poucos os grupos de plantas que podem ser considerados suficientemente bem conhecidos para que possamos utilizá-los como modelos em estudos evolutivos e de conservação. Nesse sentido, as Asclepiadoideae (Apocynaceae) do Espinhaço vêm se mostrando promissoras. Elas incluem uma grande diversidade ao longo de toda a Cadeia, com vários exemplos de endemismos (Rapini et al. 2002). Estudos florísticos com atenção especial para a subfamília na região têm sido realizados desde o início do século passado (e.g., Silveira 1908), e se intensificaram significativamente nas últimas décadas (Fontella-Pereira et al. 1984, 1995, Goyder 1995, Rapini et al. 2001, 2003a, Goyder \& Rapini in Zappi et al. 2003). Rapini (2000a) e Rapini et al. (2001, 2002; daqui em diante, Flora do Espinhaço de Minas, ou apenas FEM) reconheceram 99 espécies e 20 gêneros para a Flora de Asclepiadoideae da Cadeia do Espinhaço de Minas Gerais. A FEM apresentou 21 novidades taxonômicas, incluindo sete espécies novas, seis em Ditassa (Rapini 2002a) e uma em Oxypetalum (Rapini 2002b), além de 14 combinações, dentre elas, um nome novo e dois novos status (Rapini 2000b, 2003). Os rearranjos taxonômicos propostos ali levaram a um rompimento com a classificação pragmática e artificial, centrada na morfologia da corona, e que dominava a taxonomia das Asclepiadoideae no Brasil (Rapini 2002a). Das espécies listadas naquele levantamento, 34 foram consideradas endêmicas da Cadeia do Espinhaço, o que corresponde a pouco mais de $30 \%$ da flora, sendo a maioria restrita à porção mineira (30 espécies), com uma grande proporção de microendemismos (23 espécies). Algumas espécies não eram coletadas havia mais de 100 anos e outras eram conhecidas apenas pelo material-tipo. Devido à distribuição geográfica restrita, uma parcela significativa dessa diversidade foi considerada vulnerável, porém poucas espécies estariam criticamente ameaçadas ou extintas, estando a falta de coletas de algumas delas possivelmente associada a desvios amostrais ao longo do Espinhaço (Rapini et al. 2002).

Nessa última década, as Asclepiadoideae continuaram objeto de estudo de vários pesquisadores e tema de diversos projetos no Brasil. Desde a FEM, uma série de levantamentos florísticos (Fontella-Pereira \& Konno 2001, Konno et al. 2001, Fontella-Pereira et al. 2003, 2004, Rapini et al. 2003a, 2010a, Schwarz 2003, Farinaccio \& Mello-Silva 2004, FontellaPereira 2005, Mezabarba et al. 2006, Rapini 2006, Marquete et al. 2007, Koch et al. 2009, Monguilhott \& Mello-Silva 2008), tratamentos taxonômicos (Goyder 2003, 2004, Rapini et al. 2004, Fontella-Pereira \& Ferreira 2005, Konno 2005, Konno et al. 2006) e estudos filogenéticos (Liede \& Kunze 2002, Liede \& Täuber 2002, Rapini et al. 2003b, 2006, 2007, Konno 2005, Liede-Schumann et al. 2005, Farinaccio 2007, Goyder et al. 2007, Krings et al. 2008, Silva 2008, 2010) foram preparados. Esses trabalhos renderam descobertas importantes e promoveram mudanças significativas na taxonomia do grupo, aprimorando nossa compreensão sobre as relações internas na subfamília e a distribuição de suas espécies.
A taxonomia das Asclepiadoideae encontra-se em constante renovação e as novidades estão chegando de diversas vertentes. O objetivo deste trabalho é subsidiar taxonomicamente estudos avançados no grupo focando a flora de um de seus principais centros de diversidade no Brasil, a Cadeia do Espinhaço. Além de um guia de fotos (Rapini 2010), ampliado em 43 espécies e incluindo várias espécies raras e/ou pouco conhecidas, é apresentada uma lista revisada, ampliada e comentada da subfamília na região, atualizando o levantamento de sua porção mineira (Rapini 2000a, Rapini et al. 2001, 2002) e adicionando o da porção baiana. Esta lista é comparada ao levantamento apresentado há cerca de 10 anos para a porção mineira e são indicados aspectos da distribuição do grupo no Espinhaço que podem estar associados a padrões de diversificação na região.

\section{Material e Métodos}

Entre 2002 e 2008, foram realizadas 15 expedições de coleta no Espinhaço da Bahia e seis no Espinhaço de Minas. A FEM (Rapini et al. 2001) foi atualizada e a ela acrescentados registros das coleções depositadas nos principais herbários europeus B, BM, BR, C, G, K, LE, M, P, S, W e WU, além dos herbários nacionais ALCB, ASE, CEPEC, EAC, ESA, HAS, HRB, HST, HUEFS, IAN, ICN, INPA, IPA, JPB, MAC, PACA, MOSS, MG, TEPB, UFP, UFRN, UFRPE e VIC.

Os dados do Espinhaço de Minas foram complementados com as espécies da porção baiana. A maioria dos táxons encontra-se descrita em Rapini et al. (2001) e as espécies da Bahia estarão incluídas na Flora da Bahia (Rapini em prep.). Como ambos os tratamentos incluem/incluirão descrições detalhadas e chaves de identificação, é apresentada aqui exclusivamente uma diagnose para os táxons. Espécies que precisam ser reposicionadas taxonomicamente são indicadas com o gênero entre aspas. São apontados os países e os Estados brasileiros (GO, incluindo o DF) de ocorrência das espécies, organizados conforme a Região, e a distribuição delas na Cadeia do Espinhaço de Minas Gerais (CEMG) e da Bahia (CEBA) é resumida com base nas localidades da Fig. 1. A representatividade das espécies em cada porção do Espinhaço é evidenciada através do número de registros (entre parênteses), indicando aquelas consideradas raras segundo o catálogo de Plantas Raras do Brasil (Rapini et al. 2009). Primeiras ocorrências relevantes em Estados brasileiros e novas ocorrências para as regiões do Espinhaço de Minas (em relação a Rapini et al. 2001) são assinaladas com asterisco (*), seguida da indicação de um materialtestemunho. Dúvidas na identificação da espécie ou na localização da coleta são indicadas com interrogação (?). As Figs. indicadas para as espécies se encontram no guia de fotos (Rapini 2010).

A distribuição das coletas ao longo do tempo considera apenas aqueles materiais com ano indicado na etiqueta de herbário; foram excluídos por essa razão cerca de 200 registros, quase todos de Minas Gerais, destacando-se algumas coletas de 


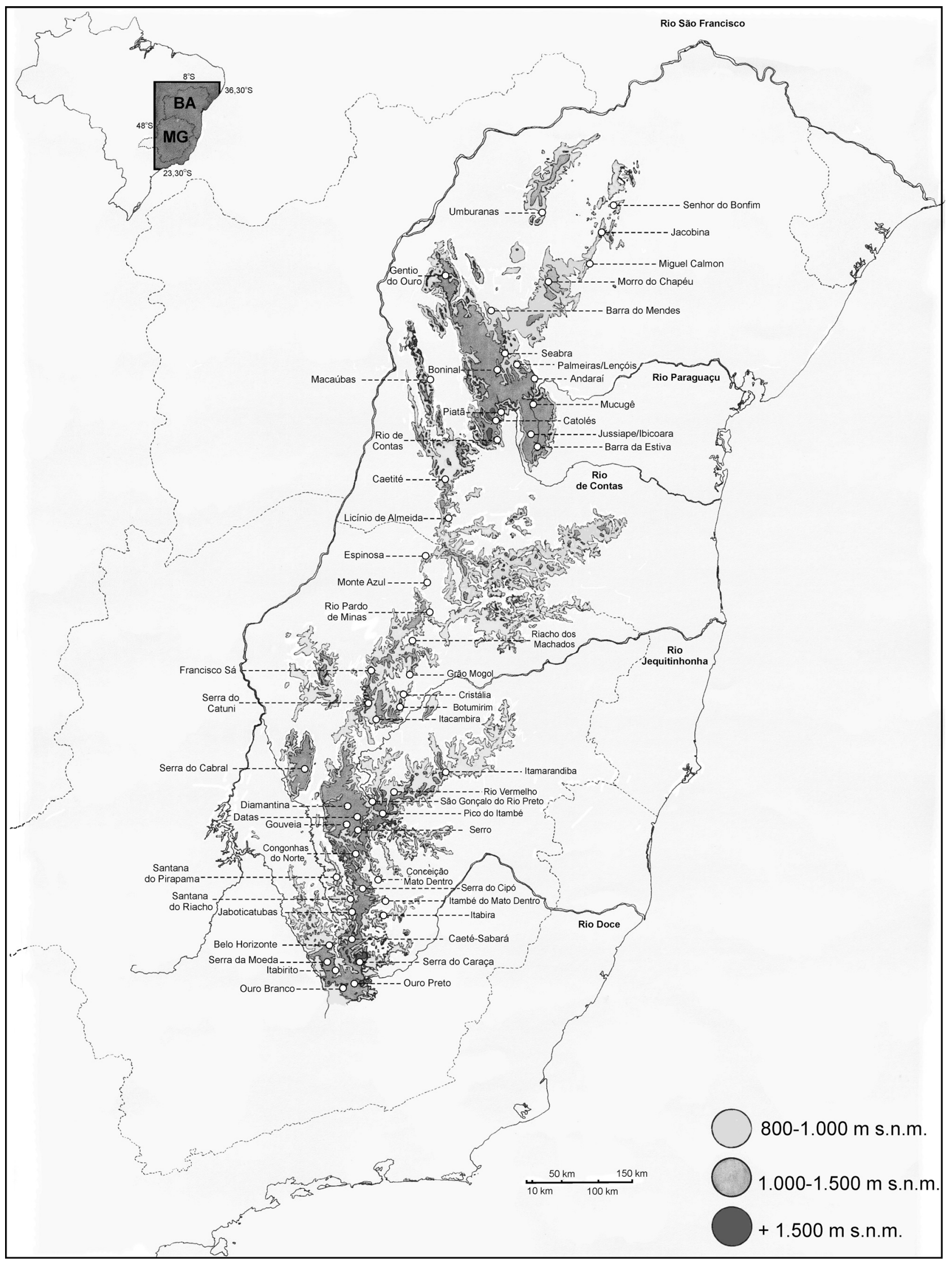

Fig. 1. Mapa da Cadeia do Espinhaço (modificada de 'Carta do Brasil ao Milionésimo', IBGE 1972), com indicação das principais localidades mencionadas no texto. 
Martius, Magalhães Gomes, Damazio e, especialmente, Badini, com cerca de 50 coletas na região de Ouro Preto descartadas nessa contagem. As regiões do Espinhaço seguem aquelas utilizadas em Rapini et al. (2002) para a porção mineira: Sul do Espinhaço, Serra do Cipó, Planalto de Diamantina e Norte do Espinhaço de Minas. Para o Espinhaço da Bahia foram consideradas três regiões: Sul do Espinhaço da Bahia (Licínio de Almeida-Macaúbas), Chapada Diamantina (bloco central, que vai de Rio de Contas e Barra da Estiva a Gentio do Ouro, passando por Seabra) e Norte do Espinhaço (de Morro do Chapéu a Senhor do Bonfim e Umburanas).

\section{Resultados}

Foram registradas cerca de 3.615 coletas de Asclepiadoideae na Cadeia do Espinhaço, cerca de 3/4 delas da porção mineira. $\mathrm{O}$ levantamento inclui 24 gêneros e 133 espécies. Os gêneros mais diversos são Ditassa (30 espécies), Oxypetalum (24) e Minaria (19), seguidos de Hemipogon (9), Matelea (8), Barjonia (5), Blepharodon (5) e Marsdenia (4); Asclepias, Cynanchum, Macroditassa, Metastelma e Schubertia, com três espécies cada; Jobinia, Nephradenia e Tassadia, com duas; e oito gêneros com apenas uma espécie: Araujia (A. sericifera),Fischeria (F. stellata), Gonolobus (G. parviflorus), Gyrostelma (G. oxypetaloides), Orthosia (O. scoparia) e Peplonia (P. organensis), além de dois gêneros introduzidos, Calotropis (C. procera) e Gomphocarpus (G. physocarpus); dessas, 99 espécies (cerca de 3/4) contam com registro fotográfico (Rapini 2010).

\section{Tratamento taxonômico}

\section{Araujia Brot.}

Inclui cerca de meia dúzia de espécies, mas estudos filogenéticos (Liede-Schumann et al. 2005, Farinaccio 2007) mostram que elas formam um grupo parafilético em relação a Morrenia Lindl., que deverá ser incluído na sinonímia de Araujia. Assim circunscrito, o gênero incluirá aproximadamente uma dúzia de espécies, tendo seu centro de diversidade no chaco, com $A$. sericifera, espécie que se estende até as Regiões Sul e Sudeste do Brasil, aparecendo como grupo-irmão do restante do clado.

1.1. Araujia sericifera Brot., Trans. Linn. Soc. London 12: 62; t. 4-5. 1817 ('sericofera').

Reconhecida pela combinação de hábito volúvel, com folhas marcadamente discolores, seríceas abaxialmente, flores relativamente grandes, com corola creme-avermelhada e polinários com retináculo provido de uma membrana apical. AMÉRICA DO SUL: Uruguai, Argentina, Paraguai e Brasil - RS, SC, PR, SP, RJ, MG - CEMG (18 - não é recoletada desde 1957): Ouro Preto-Itabira do Mato Dentro; geralmente em ambientes perturbados, borda de capoeiras, ou mesmo cultivada em cercas.

\section{Asclepias L.}

É o único gênero de Asclepiadianae nativo do Novo Mundo, aparecendo como grupo-irmão das espécies africanas da subtribo (Rapini et al. 2003b, Goyder et al. 2007). São plantas eretas, herbáceas a arbustivas, facilmente reconhecidas pelas flores em umbelas, com corola reflexa e lobos da corona cuculados, de onde parte um cornículo falcado. Abrange cerca de 120 espécies, sendo seu centro de diversidade na América do Norte.

2.1. Asclepias candida Vell., Fl. flumin.: 118. 1829; vol. 3: t. 65.1831.

Com flores alvas, semelhantes às de A. mellodora, distingue-se daquela espécie principalmente pelas folhas de lâmina coriácea, elíptica a ovada. Apesar da separação entre elas não ser problemática na região do Espinhaço, nem sempre a distinção é clara ao sul. AMÉRICA DO SUL: Argentina, Paraguai e Brasil - PR, SP, MG, GO, MS, MT, BA, SE - CEMG (19): Ouro Preto-Diamantina; CEBA (7): Rio de Contas-Mucugê e Jacobina; geralmente em campos e cerrados.

2.2. Asclepias curassavica L., Sp. pl. 1:215. 1753.

Guia: Figs. 1-3.

Distingue-se das demais espécies do Espinhaço pelas flores de corola vermelha e lobos da corona laranja. Ruderal, encontra-se espalhada pelo mundo todo, mas pelo tamanho reduzido dos cromossomos, Woodson (1954) sugeriu que a espécie deve ter se originado na América do Sul. Aparece como subespontânea, principalmente em áreas perturbadas e úmidas - CEMG (20): Ouro Preto-Serro; CEBA (9): de Catolés* (Nunes 46 - HUEFS) a Senhor do Bonfim e Gentio do Ouro.

2.3. Asclepias mellodora A.St.-Hil., Hist. pl. remarq. Brésil.: 227. 1824.

Guia: Fig. 4.

Reconhecida pelas flores alvas e folhas de lâmina estreita, geralmente linear a estreitamente elíptica, e membranácea; nos Estados do Sul, as folhas costumam ficar mais largas. AMÉRICA DO SUL: Uruguai, Argentina, Paraguai, Bolívia e Brasil - RS, SC, PR, SP, MG, GO, MS* (Corumbá: Loureiro 118 - HRB), MT, BA, SE* (Itabaiana: Silva s.n. - ASE 216) CEMG (21): Ouro Preto-Diamantina e Serra do Cabral; CEBA (3): Caetité, Rio de Contas e Jacobina; geralmente em campos e cerrados, eventualmente em dunas, afloramentos e restingas.

\section{Barjonia Decne.}

Excluindo B. harleyi, forma um grupo uniforme e altamente sustentado em análises filogenéticas (Silva 2010). São subarbustos eretos com folhas subsésseis, coriáceas e glabras, e flores campanuladas. Inclui seis espécies, a maioria em campos e cerrados do Espinhaço e do Planalto Central. 
3.1. Barjonia chloraeifolia Decne. in A.DC., Prodr. 8: 512. 1844.

Guia: Figs. 5 e 6.

Caracterizada pelas folhas patentes, de lâmina cordada na base, semi-amplexicaule, e pelas inflorescências parciais umbeliformes, geralmente com quatro flores, e subtendidas por folhas que diminuem gradativamente em direção ao ápice da planta. CEMG (46): Serra do Cipó-São Gonçalo do Rio Preto e Grão Mogol; CEBA (20): Caetité, Rio de ContasMucugê-Barra da Estiva; em campos rupestres, geralmente sobre solos pedregosos.

3.2. Barjonia erecta (Vell.) K.Schum. in Engler \& Prantl, Nat. Pflanzenfam. 4(2): 285. 1895.

Guia: Figs. 7 e 8.

Caracterizada pelas folhas patentes, de lâmina geralmente truncada na base, e pelas inflorescências parciais com uma ou duas flores e dispostas em um eixo sem folhas. AMÉRICA DO SUL: Suriname e Brasil - PR, SP, MG, GO, MS, MT, PA* (São Félix do Xingu: Gottsberger 14-17183 - HB) - CEMG (40): Ouro Branco-Grão Mogol; CEBA (2): Palmeiras e Morro do Chapéu; geralmente em cerrados.

3.3. Barjonia glazioui Marquete, Rodriguésia 31(51): 53; t. 29-33. 1979.

Reconhecida pelo tamanho reduzido, até $40 \mathrm{~cm}$ alt., pelas folhas de lâmina estreitamente triangular a lanceoladas, e inflorescencências parciais unifloras. Brasil - GO, BA* CEBA (1): Palmeiras (Carvalho 329 - HUEFS); em cerrados e campos.

3.4. 'Barjonia' harleyi Fontella, Kew Bull. 42: 663; f. 1. 1987.

Guia: Figs. 9 e 10.

Esta espécie deve ser transferida para Minaria. Distinguese prontamente de Barjonia pelo hábito mais ramificado e as folhas menores (até $6 \times 2 \mathrm{~mm}$ ). Trata-se de um subarbusto com folhas opostas, eretas, de lâmina cordiforme ou lanceolada, revoluta, e flores solitárias ou aos pares, com corola abaxialmente arroxeada, adaxialmente puberulenta, passando a pilosa para a base, lobos da corona vináceos, hexagonais, subulados a partir do terço médio, mais altos que o ginostégio. CEBA (15 - rara): Rio de Contas-Mucugê; em campos rupestres.

3.5. Barjonia laxa Malme, Ark. Bot. 4(14): 8. 1905.

Guia: Fig. 11.

Possui folhas patentes, de lâmina estreitamente triangular, semi-amplexicaule, distinguida pelas inflorescências parciais em pequeno número e geralmente com duas flores apenas. É rara no Espinhaço e as coleções encontram-se depauperadas, uma apenas com botões e outra com frutos. Brasil - MG, GO, MT - CEMG* (2 coletas da metade do século XX): Belo Horizonte (Rennó s.n. - BHCB 103) e Serra do Cipó (Mello Barreto 10265 - BHCB); em cerrados e campos.

\section{Blepharodon Decne.}

Reconhecido pelos lobos da corona naviculares e a corola com lacínias freqüentemente ciliadas. Inclui cerca de 20 espécies, mas deverá ser reduzido a apenas duas, $B$. lineare e $B$. ampliflorum, que possuem flores bem maiores que as demais espécies do gênero e, juntas, formam o grupo-irmão das demais Metastelmatinae; os resultados, no entanto, ainda são insuficientes para que decisões taxonômicas em relação às demais espécies de Blepharodon sejam tomadas (Rapini et al. 2006, Silva 2010).

4.1. Blepharodon ampliflorum E.Fourn. in Mart. \& Eichler, Fl. bras. 6(4): 304. 1885.

Guia: Figs. 12-14.

Trepadeira reconhecida pelas folhas de lâmina linear, sagitada na base, e pelas flores grandes (lacínias da corola com mais de $1 \mathrm{~cm}$ compr.), com corola verde-clara, adaxialmente com traços vináceos na base, e corona alva. Brasil - PR, SP, MG, BA, PE - CEMG (58): Ouro PretoGrão Mogol; CEBA (30): Rio de Contas-Piatã, Barra da Estiva-Palmeiras e Jacobina; geralmente em campos e borda de matas semideciduais.

4.2. 'Blepharodon' bicuspidatum E.Fourn. in Mart. \& Eichler, Fl. bras. 6(4): 306. 1885.

Guia: Fig. 15.

Trepadeira com flores de corola creme-esverdeada e corona alva; semelhante a 'Blepharodon' pictum, distinguese pelas flores geralmente menores, com lobos da corona inteiros, cimbiformes, prolongados nas duas extremidades, e com polínios elipsóides, visivelmente mais longos do que largos. Brasil - PR, SP, MG, GO, MS, MT, PA, AP* (Mazagão: Rabelo 3057 - K, MG) - CEMG (20): Belo Horizonte-Serra do Cipó; geralmente em cerrados e matas secas.

4.3. Blepharodon lineare (Decne.) Decne. in A.DC., Prodr. 8: 603. 1844.

Erva com folhas de lâmina linear e flores grandes; semelhante a $B$. ampliflorum, difere pelo hábito ereto. AMÉRICA DO SUL: Argentina, Paraguai e Brasil - RS, SC, PR, SP, MG, GO, MT, RO, MA* (Timon: Fernandes s.n. - EAC 9592) - CEMG (9): Ouro Preto-Caeté, Serra do Cipó* (Jaboticatubas: Magalhães 17020 - IAN), GouveiaBotumirim; geralmente em cerrados e campos, secos ou alagados, pedregosos ou rochosos.

4.4. 'Blepharodon' manicatum (Decne.) Fontella, Bradea 5(23): 262.1989.

Guia: Figs. 16-18.

Trepadeira geralmente híspida, facilmente reconhecida pelo conjunto de coléteres longos ( $c a .2 \mathrm{~mm}$ compr.) nos nós e na face adaxial da porção apical do pecíolo, freqüentemente próximo à base da lâmina foliar, também presentes alternadamente na axila das sépalas. As flores possuem corola esverdeada, passando a vinácea para a base, e a corona é 
creme-esverdeada. Brasil - BA, PE, CE, PI - CEBA (17): Rio de Contas-Senhor do Bonfim; geralmente em caatinga, carrascos e matas secas.

4.5. 'Blepharodon' pictum (Vahl) W.D.Stevens, Novon 10(3): 242. 2000.

Guia: Figs. 19-22.

Trepadeira com folhas de lâmina brilhante, provida de coléteres conspícuos nos nós e na base da lamina foliar, flores com corola esverdeada e corona alva, com lobos cotiliformes. Semelhante a 'Bleparodon' bicuspidatum, pode ser reconhecida pelas flores geralmente maiores, lobos da corona com duas porções fundidas e, principalmente, pelos polínios subdeltóides, tão longos quanto largos. Na FEM, foi identificada como B. nitidum (Vell.) J.F.Macbr., um sinônimo desta espécie. AMÉRICA DO SUL: Paraguai, Colômbia, Venezuela, Guiana, Suriname, Guiana Francesa e Brasil - em todo país e ao longo de todo o Espinhaço - CEMG (105) CEBA (98); geralmente em vegetações perturbadas, cerrados, campos e orla de matas.

\section{Calotropis R.Br.}

Gênero de Asclepiadinae, com três espécies nativas de regiões quentes da Ásia e da África, caracteriza-se pelas flores com lobos da corona comprimidos lateralmente e pelos frutos inflados e lisos.

5.1. Calotropis procera (Aiton) W.T.Aiton, Hortus Kew., ed. 2, 2: 78. 1811.

Guia: Figs. 23-25.

Arbusto com ramos corticosos, folhas largas e flores campanuladas, com corola alva a rósea e corona vinácea, passando a alva para a base. Introduzida no Brasil: ocorre de maneira subespontânea no Espinhaço, principalmente ao longo de estradas a partir do Planalto de Diamantina para o norte.

\section{Cynanchum L.}

As relações internas em Cynanchinae ainda não estão resolvidas (Liede \& Kunze 2002, Liede \& Täuber 2002, Rapini et al. 2003b), prejudicando a definição precisa de Cynanchum. No Novo Mundo, o gênero se restringe às cerca de 20 espécies do subgênero Mellichampia (A.Gray ex $\mathrm{S}$.Watson) E.Sundell e várias espécies americanas descritas em Cynanchum pertencem à subtribo Orthosiinae, a exemplo de Cynanchum morrenioides, e aguardam novas combinações.

$$
1824 .
$$

6.1. Cynanchum montevidense Spreng., Syst. veg. 1: 851.

Trepadeira com folhas de lâmina cordiforme, levemente cinérea, e flores de corola esverdeada, com estrias vináceas na base, rotácea, com lobos da corona sub-rômbicos a trulados, involutos sobre o ginostégio e unidos entre si na base. Caribe e AMÉRICA DO SUL: Uruguai, Argentina, Paraguai, Bolívia, Peru, Colômbia, Venezuela, Guiana, Panamá, Jamaica e Brasil - RS, PR, SP, RJ, MG, GO, MS, MT, BA, MA, PA, AM, RR, AC - CEMG (1): Espinosa; CEBA (1): Barra do Mendes; geralmente em áreas perturbadas.

6.2. 'Cynanchum' morrenioides Goyder, Kew Bull. 48: 21; t. 1, f. A-D. 1993.

Trepadeira com folhas de lâmina linear a estreitamente lanceolada (não alcançando $5 \mathrm{~mm}$ larg.) e flores de corola castanha ou esverdeada, campanulada, com corona alva, tubulosa, encobrindo o ginostégio. Com morfologia singular, aparece como grupo-irmão das demais Orthosiinae e sua classificação em Cynanchum é, portanto, provisória. CEBA (9 - rara): Rio de Contas; em campos rupestres.

6.3. Cynanchum roulinioides (E.Fourn.) Rapini, Bol. Bot. Univ. São Paulo 21(2): 278. 2003.

Guia: Figs. 26-28.

Trepadeira com folhas de lâmina cordiforme e flores pequenas (até $2,5 \mathrm{~mm}$ compr.), creme a amarelada, com corola campanulada, de tubo quase do mesmo comprimento ou mais longo que as lacínias, e corona com lobos oblongos, alternos às anteras. AMÉRICA DO SUL: Paraguai e Brasil - SP, MG, GO, MS* (Amambaí: Garcia 13707 - UEC), MT, BA, PE* (Araripina: Chiappeta CEPE525 - IPA, PEUFR), CE, PI CEMG (13): Belo Horizonte, Serra do Cipó* (Jaboticatubas: Rapini 1540-HUEFS), Serra do Cabral, Francisco Sá-Riacho dos Machados; CEBA (9): Caetité-Catolés; em cerrados, caatingas, carrascos e matas secas.

\section{Ditassa R.Br.}

Inicialmente reconhecido pelas flores com lobos da corona providos de dois segmentos, o interno por vezes atrofiado, o gênero foi recentemente reduzido, com a transferência de 19 espécies de subarbustos com folhas diminutas para Minaria. Entretanto, Ditassa continua reunindo grupos aparentemente pouco relacionados, e sua circunscrição ainda será profundamente modificada. Dados de cloroplasto indicam que as espécies de Ditassa estão divididas em três clados principais; a relação desses clados em Metastelmatinae, no entanto, não está resolvida e os resultados com dados nucleares (ITS) são incongruentes com os de plastídio (Silva 2010). Como atualmente delimitado, o gênero inclui cerca de 100 espécies; mais da metade delas ocorrem no Brasil, estando concentradas principalmente no Espinhaço (Konno 2005).

7.1. Ditassa aequicymosa E.Fourn. in Mart. \& Eichler, Fl. bras. 6(4): 248. 1885.

Guia: Figs. 29 e 30.

Trepadeira bastante ramificada, hirsuta, com folhas de lâmina arredondada, revoluta, geralmente até $1,5 \mathrm{~cm}$ 
compr., e flores de corola creme a esverdeada, com menos de $3 \mathrm{~mm}$ compr., e lobos da corona quase da mesma altura do ginostégio. CEMG (61): Ouro Preto-São Gonçalo do Rio Preto; em campos rupestres.

7.2. Ditassa auriflora Rapini, Kew Bull. 57: 570; f. 1. 2002.

Guia: Figs. 31-33.

Arbusto com folhas de lâmina linear (até 1,5 mm larg.) e flores de corola amarela, campanulada; semelhante a $D$. cordeiroana, da qual se diferencia pelo hábito ereto e as flores com corola mais longa (mais de $3 \mathrm{~mm}$ compr.) e de amarelo intenso. CEMG (8 - rara): Serra de Itacambira; em afloramentos rochosos.

7.3. Ditassa burchellii Hook. \& Arn., J. Bot. 1: 295. 1834.

Trepadeira com ramos hirsutos, folhas de lâmina elíptica, pilosa, e flores de corola campanulada, com menos de $3 \mathrm{~mm}$ compr., e lobos da corona duplos; diagnosticada pela corola adaxialmente com papilas alongadas, conspícuas na porção apical das lacínias. Na FEM, foi tratada em Metastelma. AMÉRICA DO SUL: Argentina, Paraguai e Brasil - RS, SC, PR, SP, RJ, ES, MG, MS - CEMG (3 - não é coletada desde meados de 1940): Belo Horizonte-Caeté; geralmente em orla de matas e capoeiras ou em restingas.

7.4. Ditassa capillaris E.Fourn. in Mart. \& Eichler, Fl. bras. 6(4): 253. 1885.

Guia: Figs. 34-35.

Trepadeira com folhas de lâmina linear e flores perfumadas, até 3,5 mm compr., com corola creme ou alva e corona dupla, mais baixa que o ginostégio e com os segmentos externos retangulares. Brasil - SP/RJ? (Serra da Mambucaba: Glaziou 9928 - K; id. 11199 - K, P, R), MG, BA, PE, CE, PI - CEMG (5): Cristália-Grão Mogol; CEBA (44): Licínio de AlmeidaMorro do Chapéu e Umburanas; em caatingas, cerrados, carrascos, capoeiras e campos.

7.5. Ditassa cipoensis (Fontella) Rapini, Bol. Bot. Univ. São Paulo 21: 278. 2003.

Guia: Figs. 36 e 37.

Trepadeira com ramos vilosos e folhas de lâmina elíptica, revoluta, adaxialmente hirsuta, abaxialmente vilosa ou pilosa; semelhante a $D$. tomentosa, da qual se distingue pelas lacínias da corola mais curtas (não chegando a $2,5 \mathrm{~mm}$ compr.) e lobos da corona mais largos do que longos. CEMG (14 - rara): Serra do Cipó; em campos rupestres.

7.6. Ditassa conceptionis Fontella, Dusenia 12(1): 6; f. 1. 1980.

Guia: Figs. 38 e 39.

Trepadeira com ramos hirsutos, folhas de lâmina elíptica, glabra ou quase, flores de corola alva, levemente rosada, geralmente solitárias, com lobos da corona triangulares, conspicuamente unidos entre si e com uma prega sob a antera. Brasil - SP, RJ, MG - CEMG (3): Serra do Caraça; geralmente em matinhas de altitude.
7.7. Ditassa cordeiroana Fontella, Bradea 6(27): 238. 1993.

Guia: Figs. 40-42.

Trepadeira ou arbusto volúvel, com folhas de lâmina linear (até $1 \mathrm{~mm}$ larg.), e flores de corola creme ou esverdeada; semelhante a $D$. auriflora, da qual se distingue pelo hábito volúvel e as flores menores e pálidas. CEMG (35): Botumirim-Rio Pardo de Minas; em campos, cerrados e carrascos, sobre solos arenosos ou entre rochas.

7.8. Ditassa dardanoi T.U.P.Konno \& Wanderley, Hoehnea 31: 349; f. 1. 2004.

Trepadeira pilosa a pubescente, com folhas de lâmina ovada e flores de corola alva, com lobos da corona duplos, os segmentos externos subulados, bem mais altos que o ginostégio, os internos quase da altura dele; semelhante a $D$. glazioui, da qual se distingue pelo pedúnculo das inflorescências mais longo (mais de $5 \mathrm{~mm}$ compr.), e pela corona com segmentos externos bem mais longos (mais de $3 \mathrm{~mm}$ compr.). Brasil - MG, GO, BA, CE - CEBA (1): Jacobina; principalmente em caatingas e cerrados.

7.9. Ditassa eximia Decne. in A.DC., Prodr. 8: 574. 1844. Guia: Figs. 43-45.

Trepadeira com folhas de lâmina geralmente elíptica, coriácea, glabra ou quase, e flores de corola alva, adaxialmente barbada, com lobos da corona duplos, os segmentos externos subulados, mais altos que o ginostégio, os internos cuculados, quase da altura dele. CEMG (120): Serra do Cipó-São Gonçalo do Rio Preto; em campos rupestres.

7.10. Ditassa fasciculata E.Fourn. in Mart. \& Eichler, Fl. bras. 6(4): 253; t. 71, f. 2.1885.

Guia: Figs. 46-48.

Subarbusto volúvel com folhas pequenas (lâmina até 1 $\mathrm{cm} \times 3,5 \mathrm{~mm}$ ), aglomeradas em ramos curtos, simulando fascículos, flores de corola alva a esverdeada, expondo os lobos da corona, duplos e mais altos que o ginostégio, os segmentos externos tridentados, medianamente prolongados. CEMG (72): Serra do Cipó-Itacambira, Serra do Cabral e Itamarandiba; geralmente em campos rupestres.

7.11. Ditassa glazioui E.Fourn. in Mart. \& Eichler, Fl. bras. 6(4): 250.1885

Guia: Figs. 49-51.

Trepadeira com folhas de lâmina elíptica, glabras ou quase, flores de corola creme-esverdeada, geralmente solitárias, com lobos do cálice mais longos que o tubo da corola $\mathrm{e}$ lobos da corona triangulares, quase da altura do ginostégio, conspicuamente unidos entre si. Brasil - MG, BA, PE, CE CEMG (4): Serro* (Rapini 1710 - HUEFS), Cristália e Grão Mogol; CEBA (31): Licínio de Almeida-Senhor do Bonfim; principalmente em caatingas. 
7.12. Ditassa hastata Decne. in A.DC., Prodr. 8: 575. 1844.

Guia: Figs. 52-54.

Arbusto com ramos volúveis, folhas de lâmina tipicamente triangular a trulada, glabra, e flores de corola geralmente alva, com lobos da corona duplos, os segmentos externos subulados, os internos lineares a subulados, ambos mais altos que o ginostégio. Brasil - MG, GO, TO, BA, SE, AL* (Olho d'Água do Casado: Rocha 82 - HST, MAC, RB), PE, PB, RN* (Martins: Figueiredo 323 - EAC, TEPB), CE, PI, MA - CEMG (4): Itacambira-Francisco Sá e Monte Azul; CEBA (30): Caetité-Gentio do Ouro; principalmente em caatingas, sobre solos rochosos.

7.13. Ditassa hispida (Vell.) Fontella, Bradea 3(2): 5. 1979.

Guia: Figs. 55 e 56.

Trepadeira híspida a pilosa, com folhas de lâmina elíptica, inflorescências multifloras, com flores de cálice abaxialmente hirsuto e corola creme ou amarelada, abaxialmente glabra, adaxialmente puberulenta, glabra para a base, lobos da corona duplos, os segmentos externos e internos lanceolados a lineares, da altura ou pouco mais altos que o ginostégio. AMÉRICA DO SUL: Guiana, Guiana Francesa, Argentina e Brasil - RS, PR, SP, MG, RJ, ES, BA, SE* (Itabaiana: Lucena 1804 - UFP), AL* (Fleixeiras: Lyra-Lemos 5569 MAC), PE, PB, CE* (Crato: Bezerra s.n. - EAC 535, RB), PA, MA - CEMG (7): Serra do Caraça* (Stehmann 3398 BHCB), Serro e Grão Mogol; CEBA (14): Caetité, Seabra e Senhor do Bonfim; geralmente em matas semideciduais e de restingas.

7.14. Ditassa itambensis Rapini, Kew Bull. 57: 575; f. 4. 2002.

Guia: Fig. 57.

Trepadeira hirsuta, com folhas de lâmina elíptica, revoluta, e flores de corola alva, com lobos da corona subrômbicos, quase da altura do ginostégio; semelhante a $D$. longisepala, da qual se distingue pelo pecíolo maior (pelo menos $5 \mathrm{~mm}$ compr.) e lacínias da corola eretas e vilosas adaxialmente. CEMG (4 - rara): Pico do Itambé e São Gonçalo do Rio Preto; em matinhas de altitude e campos rupestres.

7.15. Ditassa laevis Mart., Nov. Gen. sp. pl. 1: 53. 1824.

Subarbusto, geralmente prostrado a volúvel, com folhas de lâmina estreitamente elíptica, glabra ou quase, cimeiras glomeruliformes e flores de corola alva, com menos de $3 \mathrm{~mm}$ compr., e lobos da corona duplos, de segmentos lanceolados ou quase, os externos mais altos ou da altura do ginostégio, os internos mais baixos que ele, eventualmente reduzidos a pregas; semelhante a $D$. lineares, da qual se distingue pelos lobos da corona mais curtos e asas das anteras menores que o dorso. CEMG (21): Ouro Preto-Itambé do Mato Dentro; em campos rupestres.
7.16. Ditassa lenheirensis Silveira, Fl. serr. Min.: 20; t. 6. 1908.

Guia: Figs. 58 e 59.

Trepadeira com folhas de lâmina obovada a elíptica, coriácea, com tricomas esparsos, cimeiras multifloras, com flores rosadas e lobos da corona duplos, segmentos triangulares ou quase, os externos mais altos que o ginostégio, os internos mais baixos que ele; semelhante a $D$. retusa, da qual difere pelas flores rosadas, em inflorescências densas, e ginostégio brevemente estipitado. Brasil - SP* (Altinópolis: Oliveira 90 - SPF), MG, BA, GO - CEMG (8): Belo Horizonte-Serra do Cipó, Serra do Cabral e Rio Pardo de Minas* (CarneiroTorres 704 - ESA, HUEFS); CEBA (4): Caetité, Rio de Contas e Jussiape; em cerrados e campos rupestres.

7.17. Ditassa leonii Fontella \& T.U.P.Konno, Bradea 8(47): 319; f. 1. 2002.

Arbusto glabro ou quase, com folhas de lâmina largamente ovada, flores de corola alva, $c a .4 \mathrm{~mm}$ compr., adaxialmente papilosa, e lobos da corona suboblongos, conspicuamente unidos na base, quase da altura do ginostégio. Pode ser reconhecida pelas inflorescências com pedúnculo e pecíolos relativamente longos (1 cm compr. ou mais). Na FEM, foi identificada como D. myrtilloides Fenzl. ex E.Fourn., espécie que, constatou-se posteriormente, é sinônimo de $D$. linearis (Schott 5382 - W). Brasil - MG, ES - CEMG (1): Serra do Caraça; em campos de altitude.

7.18. Ditassa linearis Mart., Nov. Gen. sp. pl. 1: 53. 1824. Guia: Figs. 60-62.

Subarbusto prostrado a trepadeira, com folhas de lâmina geralmente elíptica a linear, revoluta, glabra ou quase, e flores em cimeiras glomeruliformes, com corola alva e lobos da corona duplos, de segmentos lanceolados a lineares, mais altos que o ginostégio. Brasil - MG - CEMG (64): Ouro Branco-Itabira e Serra do Cipó (apenas coletas do século XIX); em campos rupestres e cangas.

7.19. Ditassa aff. longicaulis (E.Fourn.) Rapini, Bol. Bot. Univ. São Paulo 21: 278. 2003.

Trepadeira com ramos velutino-tomentosos, folhas de lâmina estreitamente elíptica, revoluta e hirsuta, inflorescências glomeruliformes e flores de corola alva ou creme, abaxialmente hirsuta, adaxialmente tomentosa passando a barbada para a base das lacínias. Um dos seus síntipos (Widgren 45 - BR) corresponde a D. tomentosa, mas a flor da exsicata não corresponde àquela espécie; o outro síntipo (Riedel 857 - LE n.v.) foi utilizado por Konno (2005) para lectotipificar o nome. CEMG (5): Belo HorizonteSabará, Serro-Diamantina; CEBA?: Rio de Contas (Rapini 1135 - HUEFS; material com corona reduzida, carecendo de confirmação sobre sua identidade); em orla de matas.

7.20. Ditassa longisepala (Hua) Fontella \& E.A.Schwarz, Bradea 3(22): 159. 1981.

Guia: Figs. 63-65. 
Trepadeira com ramos hirsuto-tomentosos, folhas de lâmina elíptica a ovada, adaxialmente setulosa a quase glabra, abaxialmente pubescente a setulosa, inflorescências glomeruliformes, e flores com lobos do cálice longos (mais de 2,5 $\mathrm{mm}$ compr.), corola creme, levemente rosada, rotácea, adaxialmente papilosa a puberulenta paralelamente à margem das lacínias, setosa a híspida na fauce, e lobos da corona simples, sub-rômbicos, quase da altura do ginostégio. CEMG (21 - rara): Ouro Branco-Serra do Caraça; ocorrendo em capões e vegetações perturbadas.

7.21. Ditassa melantha Silveira, Fl. serr. Min.: 18; t. 5, f. 2. 1908.

Guia: Figs. 66 e 67.

Trepadeira com ramos glabros, folhas de lâmina oblonga a elíptica, com tricomas esparsos, inflorescências corimbiformes, e flores de corola vinácea, adaxialmente puberulenta, passando a hispidulosa na base, lobos da corona com ambos os segmentos maiores que o ginostégio, os externos mais longos que os internos. Na FEM, foi tratada em Macroditassa, porém estudos filogenéticos mostram que a espécie está mais relacionada aos grupos de Ditassa e 'Metastelma' do Espinhaço do que ao clado 'Macroditassa'-Peplonia (Silva 2010). CEMG (4): Serra do Cipó-Grão Mogol; CEBA (5): Rio de Contas-Palmeiras; geralmente em campos rupestres.

7.22. Ditassa mucronata Mart., Nov. Gen. sp. pl. 1: 52; t. 31, f. 2. 1824.

Guia: Figs. 68 e 69.

Trepadeira bastante ramificada, com ramos velutinotomentosos, folhas de lâmina hirsuta, elíptica e revoluta, até $2,5 \mathrm{~cm}$ compr., e flores de corola alva a esverdeada, menores que 2,5 mm compr., com lobos da corona duplos, os segmentos externos subulados, os internos lineares, ambos mais altos que o ginostégio. Brasil - SP, RJ, MG - CEMG (71): Ouro Branco-Serra do Cipó e São Gonçalo do Rio Preto* (Rapini et al. 1897 - HUEFS); em capoeiras e beira de estradas.

7.23. Ditassa obcordata Mart., Nov. Gen. sp. pl. 1: 53. 1824.

Guia: Fig. 70.

Trepadeira com ramos pubescentes, folhas de lâmina elíptica a orbicular, pequena (até $1 \mathrm{~cm}$ compr.), glabra ou quase, e flores de corola alva, com menos de $3 \mathrm{~mm}$ compr., adaxialmente puberulenta, glabrescente para a base, com lobos da corona duplos, unidos entre si na base, suboblongos, os segmentos externos geralmente maiores que o ginostégio, os internos menores que ele, às vezes atrofiados. Brasil - SP, MG, GO, BA, RO - CEMG (10): Belo Horizonte, Diamantina, Grão Mogol, Monte Azul; CEBA (14): Caetité, Piatã e Jussiape; em cerrados, campos rupestres e orla de mata.

7.24. Ditassa oxyphylla Turcz., Bull. Soc. Imp. Nat. Moscou 21(1): 260. 1848.

Trepadeira com ramos pubescentes, folhas de lâmina elíptica, híspida a pilosa, e flores de corola alva, com lobos da corona duplos, os segmentos filiformes, bem mais altos que o ginostégio; semelhante a $D$. hispida, da qual se diferencia pelas folhas marcadamente revolutas, corola abaxialmente hirsuta e adaxialmente barbelada na base das lacínias e lobos da corona mais longos (os dois segmentos com mais de $2 \mathrm{~mm}$ compr.). AMÉRICA DO SUL: Venezuela e Brasil - MG* (s/mun.: Belém 3773 - CEPEC, IAN), BA, SE, AL, PE, PB* (Maturéia: Agra 5437 - JPB); CEBA (2): Miguel Calmon; principalmente em caatingas, tabuleiros e capoeiras.

7.25. Ditassa pedunculata Malme, Ark. Bot. 28A(5): 17; f. 10.1936 .

Subarbusto a trepadeira, com folhas de lâmina obovada, glabra ou quase, flores de corola alva a creme-esverdeada, abaxialmente glabra, adaxialmente puberulenta, barbada a barbelada na base das lacínias, e lobos da corona duplos, mais altos que o ginostégio; pode ser reconhecida pelo pedúnculo das inflorescências mais longo ( $5 \mathrm{~mm}$ compr. ou mais) que os pedicelos e os segmentos externos da corona trilobados, prolongados medianamente. CEMG (9): Ouro Preto-Serra da Moeda; em campos rupestres.

7.26. Ditassa pohliana E.Fourn. in Mart. \& Eichler, Fl. bras. 6(4): 244. 1885.

Guia: Figs. 71-73.

Trepadeira com ramos velutino-tomentosos, folhas de lâmina oblonga a elíptica, revoluta, geralmente velutina, e flores de corola alvo-esverdeada a creme, abaxialmente hirsuta, adaxialmente puberulenta, hispidulosa para a base, com lobos da corona oblongos, mais baixos que o ginostégio. Brasil - MG, BA - CEMG (10): Diamantina* (Rapini 1784 HUEFS) e Cristália-Monte Azul; CEBA (21): Rio de ContasJacobina e Umburanas; principalmente em carrascos.

7.27. Ditassa retusa Mart., Nov. Gen. sp. pl. 1: 53. 1824. Guia: Figs. 74-77.

Trepadeira com folhas de lâmina elíptica a obovada, glabra ou quase, e flores de corola alva ou creme, abaxialmente glabra, adaxialmente puberulenta, barbelada a glabra na base das lacínias, com lobos da corona duplos, segmentos lanceolados, os externos mais altos que o ginostégio, os internos mais baixos que ele. Brasil - SP, MG, BA - CEMG (77): Ouro Preto-Riacho dos Machados e Serra do Cabral; CEBA (113): Caetité e Piatã, Ibicoara-Jacobina e Umburanas; principalmente em campos rupestres.

7.28. Ditassa rotundifolia (Decne.) Baill. ex K.Schum., Nat. Pflanzenf. 4(2): 242. 1895.

Guia: Figs. 78 e 79.

Trepadeira com ramos hirsutos, folhas de lâmina geralmente orbicular, pilosa a quase glabra, coriácea, e flores de corola alva a esverdeada, com mais de $5 \mathrm{~mm}$ compr., abaxialmente hirsuta, adaxialmente puberulenta, passando a hispidulosa para a base das lacínias, com lobos da corona oblongos, pouco mais altos que o ginostégio. Brasil - BA, 
SE, PE - CEBA (23): Barra da Estiva-Senhor do Bonfim; em campos rupestres e campos gerais.

7.29. Ditassa succedanea Rapini, Bol. Bot. Univ. São Paulo 21: 278. 2003.

Guia: Figs. 80 e 81.

Trepadeira ou subarbusto, com ramos hirsutos a glabros, folhas de lâmina oblonga a suborbicular, glabra ou quase, coriácea, e flores de corola alva; semelhante a $D$. eximia, da qual se distingue pela corola adaxialmente glabra, ao menos no centro das lacínias, e com tricomas retrorsos esparsos na base, e pelos segmentos internos da corona planos e lanceolados, da altura ou mais altos que o ginostégio. Brasil MG, BA - CEMG (33): Serra do Cipó-Rio Pardo de Minas e Serra do Cabral; CEBA* (1): Piatã (Sano CFCR66 - ESA, K, NY, SPF); em campos rupestres.

7.30. Ditassa tomentosa (Decne.) Fontella, Bol. Bot. Mus. Munic. 39: 1. 1979.

Trepadeira com ramos velutino-tomentosos, folhas de lâmina elíptica, pelo menos $3 \mathrm{~cm}$ compr., revoluta, hirsuta, e flores em inflorescência glomeruliformes, com corola alva, abaxialmente glabra, adaxialmente tomentosa, pilosa na fauce, e lobos da corona sub-rômbicos; pode ser reconhecida pelas flores com lacínias da corola longas (mais de $4 \mathrm{~mm}$ compr.). Brasil - PR, SP, RJ, MG, GO - CEMG (33): Ouro PretoCaeté; em cerrados, matas ciliares e vegetações perturbadas.

\section{Fischeria DC.}

Gênero com sete espécies e centro de diversidade próximo ao Ístmo do Panamá, da Colômbia à Costa Rica, mas com Fischeria scandens Decne. alcançando o México e F. stellata, o sul do Brasil (Murphy 1986). Está incluído, em Gonolobinae, proximamente relacionado a Macroscepis e Schubertia (Krings et al. 2008), sendo definido pelas flores com um dos lobos da corola com margem crispada e as anteras com apêndice dorsal carnoso.

8.1. Fischeria stellata (Vell.) E.Fourn. in Mart. \& Eichler, Fl. bras. 6(4): 301. 1885.

Trepadeira com ramos pilosos, folhas de lâmina elíptica a cordiforme, grande (mais de $8 \mathrm{~cm}$ compr.), velutino-estrigosa, inflorescências longipedunculadas (pedúnculo com mais de 5 $\mathrm{cm}$ compr.), multifloras, e flores longipediceladas (pedicelo com mais de 1,5 cm compr.), com corola alva e corona verde, colunar, aneliforme na base. No Espinhaço, é conhecida apenas por duas coletas com localidades imprecisas: uma, em direção à Serra do Cipó, outra, em Jacobina, o tipo de F. rotundifolia Decne. $(=F$. stellata). AMÉRICA DO SUL: Argentina, Paraguai, Bolívia, Peru, Equador, Colômbia, Venezuela, Trinidade e Brasil - RS, SC, PR, SP, RJ, ES, MG, GO, MS, MT, BA, MA, PA, AM, AP, RO, RO, AC-CEMG*?: em direção à Serra do Cipó (Duarte 8804 - HB, HUEFS, RB); CEBA (1): Jacobina; em orla de matas e capoeiras.

\section{Gomphocarpus R.Br.}

De origem africana, conta com cerca de 20 espécies (Goyder \& Nicholas 2001), algumas cultivadas e, por vezes, ocorrendo de maneira subespontânea nas Américas. São erva e arbustos semelhantes a Asclepias, porém sem cornículo nos lobos da corona e com folicários freqüentemente inflados .

9.1. Gomphocarpus physocarpus E.Mey., Comm. pl. Afr. austr.: 202. 1838.

Guia: Figs. 82 e 83.

Caracterizada pelas flores com lacínias da corola geralmente alvas, esverdeadas para o ápice, reflexas, com uma das margens ciliada, corona com lobos rosados e folicários globosos, equinados. Cultivada no Brasil - CEMG: Ouro Preto-Serra do Cipó; ocorrendo de maneira subespontânea.

\section{Gonolobus Michx.}

Inclui entre 100 e 130 espécies, mas sua circunscrição ainda é discutível. Os estudos filogenéticos carecem de uma amostragem ampla de Gonolobinae e seus resultados ainda não apresentaram resolução suficiente para uma definição consistente de Gonolobus. Todavia, duas características podem ajudar na identificação do gênero: o apêndice laminar carnoso sobre o dorso das anteras e os folicários profundamente carenados a alados (Krings et al. 2008).

10.1. Gonolobus parviflorus Decne. in A.DC., Prodr. 4: 597. 1844.

Guia: Figs. 84-86.

Trepadeira hirsuta a híspida, com folhas cordiformes, eventualmente auriculadas na base, flores de lacínias verdes, com nervação marcada, patentes a reflexas, corona creme, anular, com lobos internos ligulados, abaixo do ginostégio estipitado, e folicários verdes, costados. Na FEM, foi identificada como G. selloanus (E.Fourn.) Bacigalupo, um sinônimo desta espécie (Fontella et al. 2004). AMÉRICA DO SUL: Argentina, Paraguai e Brasil - RS, SC, PR, SP, RJ, MG, MS* (Bonito: Hatschbach 74450 - HUEFS, MBM), MT, BA*, (Itabuna-Ilhéus: Hage 1252 - CEPEC, RB), PA?* (Santana do Araguaia: Plowman 8848 - INPA, MG) - CEMG (8): Ouro Preto; em matas e capoeiras.

\section{Gyrostelma E.Fourn.}

Gênero com duas espécies, eventualmente tratado na sinonímia de Matelea. No entanto, diferencia-se daquele gênero pela corona membranácea, paralela ao ginostégio, e pelos polínios em estádio intermediário entre pendente e horizontal.

11.1. Gyrostelma oxypetaloides E.Fourn. in Mart. \& Eichler, Fl. bras. 6(4): 303; t. 87. 1885. 
Subarbusto piloso, com folhas elípticas e flores quase glabras, em inflorescências glomeruliformes, com lobos da corona bicorniculados, mais altos que o ginostégio. Brasil MG, GO - CEMG (1): Serra do Cipó; geralmente em cerrado.

\section{Hemipogon Decne.}

Inclui cerca de 10 espécies, com centro de diversidade no Espinhaço e no Planalto Central. São plantas eretas a volúveis, vegetativamente glabras ou quase, caracterizadas principalmente pelas folhas de lâmina estreita, filiformes a estreitamente elípticas, e as flores com corola geralmente urceoladas a campanuladas. A proximidade filogenética entre as espécies eretas tratadas anteriormente em Metastelma e as volúveis tratadas em Astephanus R.Br. (Rapini 2002a) foi confirmada (Silva 2008, 2010). A posição da espécie tipo do gênero (H. acerosus), no entanto, não está resolvida dentre as Metastelmatinae e o clado formado pelas espécies de Hemipogon do Espinhaço poderá compor um gênero à parte que, como Minaria, denotará uma linhagem críptica e que havia passado despercebida com base exclusivamente nos estudos morfológicos.

12.1. Hemipogon abietoides E.Fourn. in Mart. \& Eichler, Fl. bras. 6(4): 196. 1885.

Guia: Figs. 87 e 88.

Subarbusto até $20 \mathrm{~cm}$ alt., com folhas de lâmina acicular, espiraladamente dispostas, obliquamente eretas e imbricadas, lembrando a miniatura de um pinheiro, e flores de corola vinácea, abaxialmente com tricomas introrsos paralelamente às margens das lacínias e um tufo de tricomas retrorsos na base delas, e lobos da corona oblongos a lanceolados, pouco maiores que o ginostégio. Após mais de 180 anos sem registros, foi recoletada em 2007 e 2008 na Serra da Lapa, ao longo da estrada que liga Santana do Riacho e Congonhas do Norte (Rapini et al. 2010b). CEMG (3 - rara): Serra do Cipó; em campos rupestres, sobre solos pedregosos.

12.2. Hemipogon acerosus Decne. in A.DC., Prodr. 8: 509. 1884.

Guia: Figs. 89 e 90.

Subarbusto até $30 \mathrm{~cm}$ alt., com folhas de lâmina acerosa, verticiladas, obliquamente eretas, flores de corola creme, abaxialmente seríceo-tomentulosa no terço superior e barbada na região mediana, sem corona. Brasil - SP, $\mathrm{MG}, \mathrm{GO}, \mathrm{MS} *$ (Amambaí: Garcia 13831 - UEC), MT, TO* (Palmas: Sobral 10414 - BHCB), BA* (Barreiras: Zehntner 3012 - M), RO* (Vilhena: Vieira 668 - INPA) - CEMG (18): Ouro PretoSerra do Catuni, Serra do Cabral e Itamarandiba; em cerrados e campos.

12.3. Hemipogon carassensis (Malme) Rapini, Bol. Bot. Univ. São Paulo 21: 278. 2003.

Guia: Figs. 91-93.
Trepadeira com folhas de lâmina linear a estreitamente elíptica e flores de corola alva a esverdeada, adaxialmente barbada no ápice das lacínias, serícea na metade superior do tubo e glabra na basal, sem corona; semelhante a $H$. piranii, distingue-se pelo indumento da corola e pelas anteras com alas laterais falcadas na porção apical. Brasil - SP, MG, BA - CEMG (75): Ouro Branco-Rio Pardo de Minas e Serra do Cabral; CEBA (13): Caetité-Rio de Contas-Palmeiras; geralmente em cerrados e campos rupestres.

12.4. Hemipogon furlanii (Fontella) Rapini, Bol. Bot. Univ. São Paulo 21: 278. 2003.

Guia: Figs. 94 e 95.

Trepadeira com folhas filiformes e flores de corola alva a rósea, sem corona; vegetativamente semelhante a $H$. luteus, pode ser distinguida pelas flores, com corola de lacínias mais longas (mais de $3 \mathrm{~mm}$ compr.), contorcidas e abaxialmente vilosas. CEMG (3 - rara): Serra do Catuni; em carrasco.

12.5. 'Hemipogon' harleyi (Fontella) Goyder, Kew Bull. 59(3): 445. 2004.

Guia: Figs. 96 e 97.

Esta espécie deve ser transferida para Minaria. Sua proximidade com as espécies daquele gênero foi revelada a partir de dados moleculares (Silva 2008, 2010), porém destaca-se prontamente delas pelo hábito volúvel, as folhas lineares e o ápice do ginostégio rostrado, vináceo-esverdeado e cilíndrico. Possui flores de corola alva no tubo, passando a castanho-esverdeada para as lacínias, adaxialmente papilosa a puberulenta, porém barbada no eixo das lacínias próximo à fauce, e lobos da corona triangulares, mais baixos que o ginostégio. CEBA (4 - rara): Catolés e Mucugê; em campos rupestres.

12.6. Hemipogon hatschbachii (Fontella \& Marquete) Rapini, Bol. Bot. Univ. São Paulo 21: 278. 2003.

Guia: Figs. 98 e 99.

Subarbusto $c a .50 \mathrm{~cm}$ alt., folhas de lâmina filiforme, opostas e eretas, e flores de corola vinácea, adaxialmente com tricomas introrsos paralelamente às margens das lácinias, barbelada no centro delas e com tufo de tricomas no tubo, lobos da corona estreitamente oblongos e quase da altura do ginostégio, eventualmente atrofiados. CEMG (4 - rara): Serra do Cipó; em campos rupestres.

12.7. Hemipogon hemipogonoides (Malme) Rapini, Bol. Bot. Univ. São Paulo 21: 278. 2003.

Guia: Figs. 100-102.

Subarbusto $c a .50 \mathrm{~cm}$ alt., folhas de lâmina acerosa a linear, opostas, eretas, e flores de corola geralmente creme, adaxialmente seríceo-tomentulosa, barbada na base das lacínias, com lobos da corona lineares, mais altos que o ginostégio. CEMG (56): Ouro Preto-Serra do Catuni e Serra do Cabral; em campos rupestres. 
12.8. Hemipogon luteus E.Fourn. in Mart. \& Eichler, Fl. bras. 6(4): 197. 1885.

Guia: Figs. 103-105.

Trepadeira com folhas de lâmina filiforme e flores com corola geralmente alva, adaxialmente puberulentas, sem corona. CEMG (52): Serra do Cipó-Diamantina; em campos rupestres.

12.9. Hemipogon piranii (Fontella) Rapini, Bol. Bot. Univ. São Paulo 21: 278. 2003.

Trepadeira com folhas de lâmina linear e flores de corola alva; vegetativamente semelhante a $H$. carassensis, pode ser distinguida pelas flores com corola adaxialmente barbada na base das lacínias e pelas anteras com asas laterais triangulares. CEMG (6 - rara): Santana do Pirapama; em campos rupestres.

\section{Jobinia E.Fourn.}

Pertence a Orthosiinae (Liede-Schumann et al. 2005) e inclui cerca de 10 espécies, com centro de diversidade na Mata Atlântica, entre o Paraná e o Rio de Janeiro. São trepadeiras vegetativamente glabras, com folhas de lâmina ovada a elíptica, inflorescências axilares, multifloras, ramificadas, flores com corola clara e frutos com os dois folicários desenvolvidos, sendo caracterizadas principalmente pelos lobos da corona trilobulados, prolongados medianamente, longamente soldados entre si.

13.1. Jobinia connivens (Hook. \& Arn.) Malme, Bull. Soc. Bot. Genève, ser. 2, 3: 274. 1911.

Tipicamente, apresenta polínios armados, característica não observada nas plantas da Chapada Diamantina. Além disso, os lobos da corona não se encontram fundidos, como é característico do gênero e enfatizada em seu epíteto específico. Brasil - RS, SC, PR, SP, RJ, MG, BA; CEMG* (1): Ouro Branco (Glaziou 15225a p.p. - P); CEBA (1?): Palmeiras; em matas, capões e restingas.

13.2. Jobinia lindbergii E.Fourn. in Mart. \& Eichler, Fl. bras. 6(4): 327. 1885.

Caracterizada pelas inflorescências laxas e flores com lacínias mais longas (mais de 3,5 mm compr.), e corona mais alta, superando o ginostégio. Brasil - PR, SP, MG, GO, BA CEBA (2): Rio de Contas-Catolés; principalmente em matas e capoeiras.

\section{Macroditassa Malme}

Inclui cerca de 15 espécies, a maioria no Brasil (FontellaPereira \& Ferreira 2005). São trepadeiras vegetativamente glabras ou quase, definidas pela combinação de inflorescências axilares, opostas, e flores com lobos da corona duplos. Uma parte de suas espécies, incluindo a espécie-tipo do gênero, M. adnata, forma um grado em relação ao gênero Peplonia, também caracterizado pelas inflorescências axilares e que, por ter prioridade sobre Macroditassa, deverá incluí-lo em sua sinonímia (Silva 2010).

14.1. 'Macroditassa' adnata (E.Fourn.) Malme, Ark. Bot. 21A(3): 10; t. 72.1927.

Guia: Figs. 106 e 107.

Reconhecida pelas flores relativamente pequenas (até $2 \mathrm{~mm}$ compr.), de corola clara, adaxialmente puberulenta, passando a setosa na base, com lobos da corona de segmento externo pouco mais altos que o ginostégio e interno mais baixo que ele. Brasil - PR, SP, MG, GO, MS, MT, BA, PE* (Caruaru: Rodal 599 - K, PEUFR) - CEMG (9): ItabiritoCaeté e Grão Mogol; CEBA (2): Catolés e Miguel Calmon; geralmente em matas ciliares, capoeiras e orla de matas.

14.2. 'Macroditassa' grandiflora (E.Fourn.) Malme, Ark. Bot. 28A(5): 23. 1936.

Distingue-se pelas flores maiores (mais de $5 \mathrm{~mm}$ compr.), corola adaxialmente puberulenta, com tricomas longos na base das lacínias, e segmentos interno e externo dos lobos da corona subulados, ambos superando longamente o ginostégio. Brasil - MG*, RJ, ES, BA - CEMG* (1): Serra do Caraça (Wainio s.n. - S); CEBA (1): Morro do Chapéu; geralmente em restingas e orla de matas.

14.3. 'Macroditassa' macrophylla Malme, Ark. Bot. 28A(5): 4. 1936.

Guia: Figs. 108 e 109.

Caracterizada pelas folhas quase suculentas e as flores maiores (mais de $6 \mathrm{~mm}$ compr.), com corola de tubo quase tão longo quanto as lacínias, densamente puberulenta adaxialmente, passando a barbada para a base, e lobos da corona com segmentos mais altos que o ginostégio, o externo bem mais mais longo que o interno. Brasil - RJ, MG, BA* - CEMG* (1): Serra do Cipó (Conceição do Mato Dentro: Mota 2069 - BHCB); CEBA (4): Palmeiras (Melo PCD 1781 - ALCB, CEPEC, SPF); em orla de matas e em campos rupestres.

\section{Marsdenia R.Br.}

É o único gênero brasileiro de Marsdenieae, subtribo caracterizada pelas flores com polínios eretos, mas sua circunscrição e a relação com os demais gêneros da subtribo ainda não estão resolvidas. A delimitação mais abrangente de Marsdenia inclui mais de 300 espécies, principalmente tropicais. No Brasil, são encontradas cerca de 35 espécies, incluindo trepadeiras, principalmente nas regiões mais úmidas, e arbustos, nas regiões mais secas.

15.1. Marsdenia altissima (Jacq.) Dugand, Mutisia 9: 1. 1952.

Guia: Fig. 110.

Trepadeira distinguida pelo indumento velutino-tomentoso da parte vegetativa, folhas de lâmina cordiforme, grande (pelo 
menos $8 \times 8 \mathrm{~cm}$ ), flores de corola vinácea, pequenas (menos de $8 \mathrm{~mm}$ compr.), em inflorescências multifloras (mais de 10 flores), e frutos grandes (mais de $15 \mathrm{~cm}$ compr.) e vilosos. AMÉRICA DO SUL: do norte da Argentina à Colômbia, e no Brasil - SP, RJ, MG, GO, MS, MT, BA, SE, AL, PE, PB, RN, CE, PI, MA, PA, RO, RR - CEMG (4): Belo Horizonte, Serra do Cipó e Monte Azul; CEBA (4): Rio de Contas e Senhor do Bonfim; principalmente em caatingas, mas também em orla de matas mesófilas e semideciduais, restingas, cerrados e afloramentos calcários.

15.2. Marsdenia hilariana E.Fourn. in Mart. \& Eichler, Fl. bras. 6(4): 322. 1885.

Guia: Figs. 111 e 112.

Trepadeira vegetativamente glabra ou quase, com folhas de lâmina elíptica, cuneada na base e coriácea, flores de corola vinácea, pequenas (menos de $1 \mathrm{~cm}$ compr.), e frutos grandes (mais de $10 \mathrm{~cm}$ compr.) e glabros. Na FEM, foi tratada dentro de uma delimitação mais inclusiva de M. macrophylla (Humb. \& Bonpl. ex Schult.) E.Fourn., espécie que pode ser distinguida desta pelas folhas maiores e cordadas na base, além de lobos da corona mais altos que o ginostégio. AMÉRICA DO SUL: Uruguai e Brasil - RS, SC, PR, SP, RJ, ES, MG, GO, MT, BA, AL - CEMG (1): Serra do Caraça; CEBA (1): Mucugê; em matas úmidas, matas ciliares, caatingas e restingas.

15.3. Marsdenia suberosa (E.Fourn.) Malme, Bih. Kongl. Svenska Vetensk.-Akad. Handl. 34(7): 94. 1900.

Guia: Figs. 113 e 114.

Trepadeira com ramos unilateralmente pubescentes, folhas de lâmina elíptica a oblonga, até $10 \mathrm{~cm}$ compr., glabra e membranácea, e flores com corola amarela, freqüentemente passando a esverdeada para a base, com mais de $1 \mathrm{~cm}$ compr., urceolada. Brasil - RJ, MG, BA - CEMG (9): Gouveia-Grão Mogol; CEBA (6): Catolés e Seabra; em matas semideciduais, freqüentemente associadas a campos rupestres.

15.4. Marsdenia zehntneri Fontella, Sellowia 17: 62; t. 1. 1965.

Guia: Figs. 115-117.

Arbusto até $2 \mathrm{~m}$ alt., com folhas de lâmina estreitamente lanceolada a sublinear, glabra ou quase, membranácea, flores de corola amarelada, com mais de $1 \mathrm{~cm}$ compr., e frutos grandes (mais de $10 \mathrm{~cm}$ compr.) e glabros. Brasil - MG, GO, BA - CEBA (1): Rio de Contas; associada a afloramentos de calcário, sejam em áreas abertas ou em matas semideciduais.

\section{Matelea Aubl.}

Inclui cerca de 300 espécies, mas sua circunscrição ainda é controversa. Os estudos filogenéticos (Krings et al. 2008) ainda não foram capazes de oferecer uma estruturação para as relações em Gonolobinae e a aceitação ou não de vários dos sinônimos de Matelea continua sustentada em opiniões quanto à importância no grau de distinção morfológica desses táxons. Pode ser distinguida de Gonolobus principalmente pela ausência de uma membrana laminar sobre o dorso das anteras e pelos frutos geralmente muricados, com protuberâncias lenticelares ou projeções filiformes.

16.1. Matelea denticulata (Vahl) Fontella \& E.A.Schwarz, Bol. Mus. Bot. Munic. 46: 41981.

Treapadeira com ramos pilosos, folhas de lâmina elíptica, cordada na base, esparsamente ciliada, flores com corola rotácea, verde, e corona aneliforme, sinuosa, abaixo das anteras. Do México à AMÉRICA DO SUL: Argentina, Paraguai, Colômbia, Venezuela, Guiana, Suriname, Guiana Francesa e Brasil - RS, SC, PR, SP, MG, GO* (DF: Ramalho 170 - UEC), TO, MT, BA* (Itapicuru: Borges $12-\mathrm{HRB}$, RB), CE, PA, AM* (rio Purus: Prance 16288 - INPA), RR, AC - CEMG (2): Belo Horizonte (coletada pela última vez em 1903) e Francisco Sá? (Irwin 23218 - IAN); em capoeiras e orla de matas.

16.2. Matelea endressiae Goes \& Fontella, Novon 19: 41. 2009.

Guia: Figs. 118-120.

Trepadeira com ramos híspidos, passando a escabrosos, e puberento-glandulosos, folhas de lâmina ovada, auriculada na base, com tricomas longos, falciformes e pungentes, associados a tricomas menores e glandulares, flores com corola rotácea, verde, corona aneliforme, sinuosa, quase da altura do ginostégio, e frutos equinados, com projeções falciformes. Brasil - MG* (Engenheiro Dolabela: Duarte 7765 - HB), BA* (Rodelas: Rapini 1233 - HUEFS-2), PE* (Venturosa: Costa 51 - PEUFR), PB* (São José dos Cordeiros: Barbosa 2685 - HUEFS, JPB), RN (Jucurutu: Oliveira 1214 - MOSS), CE - CEBA (2): Senhor do Bonfim; principalmente em caatingas, mas também em matas semideciduais associadas a inselbergues e afloramentos de calcário.

16.3. Matelea ganglinosa (Vell.) Rapini, Neodiversity 3 : 19. 2008.

Guia: Figs. 121 e 122.

Trepadeira com ramos pubescentes a tomentosos, folhas de lâmina geralmente cordiforme, adaxialmente híspida, abaxialmente vilosa a lanosa, reconhecida pelas flores de corola vinácea, eventualmente esverdeada, rotácea, e corona aneliforme, sinuosa e papilosa ao longo da crista, mais baixa que o ginostégio, e pelos frutos com projeções filiformes. Assemelha-se a M. maritima (Jack.) Woodson, espécie restrita ao norte da América do Sul, mas que possui flores com apêndice do ginostégio conspicuamente rostrado e/ou frutos muricados, sem projeções filiformes, mais semelhantes aos de M. nigra. Brasil - MG, RJ, ES, BA, SE, AL, PE (incluindo Fernando de Noronha), PB, RN, CE, MA - CEBA (15): Rio de Contas-Catolés e Morro do Chapéu-Senhor do Bonfim; em restingas, passando por bordas de floresta atlântica e adentrando às caatingas. 
16.4. Matelea harleyi Fontella \& Morillo, Ernstia 3(3-4): 117. 1994.

Guia: Fig. 123.

Trepadeira com ramos hirsutos, glandulosos, folhas de lâmina ovada a oblonga, cordada a auriculada na base, flores com corola alva, campanulada, de tubo quase do mesmo comprimento das lacínias, corona pentalobada, com lobos suboblongos a panduriformes, tridentados no ápice, e frutos com granulações alvas esparsas. Brasil-BA, PE* (Mirandiba: Gomes 298 - HUEFS), CE* (Grajal: Araújo 1543 - EAC, HUEFS-2), RN (Serra Negra: Queiroz 370 - HUEFS, JPB, MAC, UFRN) - CEBA (1): Senhor do Bonfim; em caatingas.

16.5. Matelea morilloana Fontella, Bradea 6(8): 62; t. 1. 1992.

Trepadeira com ramos hirsutos, folhas de lâmina cordiforme, adaxialmente híspida a hirsuta, abaxialmente hirsuta a subtomentosa, e flores de corola vermelho-escura a púrpura, com corona pentalobada, de lobos tridentados, soldados até o ápice. CEBA (3 - rara): Caetité e Rio de Contas; em vegetação perturbada.

16.6. Matelea nigra (Decne.) Morillo \& Fontella, Ernstia 57: 2. 1990.

Guia: Figs. 124-126.

Trepadeira com ramos puberulentos a híspido-glandulosos, folhas de lâmina ovada, reniforme na base, estrigulosa a híspida, eventualmente com tricomas glandulosos próximo à margem, flores de corola alva ou vinácea, com nervação marcada, corona pentalobada, cada lobo bicorniculado e medianamente ondulado, e frutos com granulações alvas ao longo da superfície. Apresenta dois padrões relacionados às dimensões florais, mas a separação entre eles exigirá investigações mais detalhadas. Brasil - MG, BA, AL, PE, PB, RN, CE, PI - CEMG* (2): Itacambira (Farinaccio 682 - ESA, HUEFS, MBM, RB, SPF) e Mato Verde (Forzza 4060 - HUEFS); CEBA (16): Rio de Contas-Catolés, Gentio do Ouro, Morro do Chapéu-Senhor do Bonfim; geralmente em caatingas, mas também em orla de matas semideciduais e afloramentos rochosos.

16.7. Matelea orthosioides (E.Fourn.) Fontella, Bradea 4(9): 55. 1984.

Guia: Figs. 127 e 128.

Trepadeira com ramos pubescentes a glabrescentes, folhas de lâmina elíptica a ovada, glabra ou quase, flores de corola verde, com nervação marcada, rotácea a reflexa, com corona roxa a amarronzada, formada por cinco lígulas carnosas sob as anteras, e frutos carenados. Brasil - PR* (Paranaguá: Hatschbach 58541 - BR, C, HUEFS), SP, RJ* (Rio das Ostras: Braga 6483 - HB), ES, MG* (Ituiutaba: Macedo 361 - BM, C, S, SP, UB), GO, BA, SE, AL, PE* (Cabo de Santo Agostinho: Cantarelli 200 - PEUFR), PB, PA*? (Pau d'Arco: Grogan 34 - IAN, INPA, MG), AM*? (Manaus: Prance 15983 - INPA) - CEBA (3): Palmeiras; principalmente em matas litorâneas, mas também encontrada em matas de grotão e possivelmente em matas de terra-firme, na Região Norte.
16.8. Matelea pedalis (E.Fourn.) Fontella \& E.A.Schwarz, Bol. Mus. Bot. Munic. 46: 7. 1981.

Guia: Figs. 129 e 130.

Trepadeiras com ramos glabrescentes, folhas de lâmina ovada a estreitamente elíptica, glabra ou quase, flores de corola verde a ocre, rotácea, com corona atropurpúrea, aneliforme, brevemente pentalobada, cada lobo com uma lígula abaixo da antera, e frutos carenados. Na Região Centro-Oeste, é encontrada como arbusto ereto, com folhas mais estreitas, quase lineares; o reconhecimento taxonômico dessa variação, no entanto, requer uma análise da variação ao longo de toda a sua distribuição. Brasil - MG, GO, MS, MT, BA - CEMG (20): Ouro Preto-Serra do Cipó e Diamantina* (Farinaccio 532 - SPF); CEBA (5): Rio de Contas; em campos e matas ciliares, sempre associada a riachos, geralmente com parte da planta submersa.

\section{Metastelma R.B.}

Tradicionalmente distinguido de Ditassa pelas flores com lobos da corona providos de um único segmento e ginostégio geralmente estipitado. As espécies do norte da América do Sul e da América Central formam um clado, enquanto as espécies endêmicas do Espinhaço parecem estar mais relacionadas às espécies de Ditassa, pelo menos com base em dados de plastídio (Silva 2010). Ainda assim, a falta de suporte e o conflito com os dados nucleares vêm dificultando a circunscrição segura do gênero. Inclui cerca de 70 espécies (Liede \& Meve 2004), mas as endêmicas do Espinhaço da Bahia deverão ser excluídas de Metastelma caso uma definição menos inclusiva seja adotada para o gênero.

17.1. 'Metastelma' giuliettianum Fontella, Phytologia 59(4): 224. 1986.

Guia: Figs. 131 e 132.

Trepadeira pilosa, com folhas de lâmina elíptica e revoluta, flores de corola alva, eventualmente rosada para a base, tubulosa, $c a .5 \mathrm{~mm}$ compr., abaxialmente hirsuta, adaxialmente vilosa, com lobos da corona simples, lanceolados, mais altos que o ginostégio. Apesar da morfologia singular, estudos filogenéticos com dados moleculares sugerem sua afinidade com as demais espécies de Metastelma do Espinhaço e com espécies de Ditassa (Silva 2010). CEBA (12 - rara): Rio de Contas-Mucugê; em campos rupestres.

17.2. 'Metastelma' harleyi Fontella, Phytologia 59(4): 225. 1986.

Guia: Figs. 133 e 134.

Trepadeira com folhas de lâmina elíptica, glabra ou quase, e flores de corola alva; semelhante a $D$. retusa, porém com lobos da corona simples e lanceolados. CEBA (19): Rio de Contas-Mucugê e Morro do Chapéu? (Mori 14538 - CEPEC, RB; considerada uma possível subespécie por Fontella in sched.); em campos rupestres. 
17.3. 'Metastelma' myrtifolium Decne. in A.DC., Prodr. 8: 514.1844.

Guia: Figs. 135-137.

Erva com ramos hirsutos a pubescentes, folhas obliquamente eretas, de lâmina ovada a elíptica, coriácea, e flores em fascículos multifloros, com corola tubulosa, de lacínias recurvadas, abaxialmente rosadas a esverdeadas, adaxialmente alvas e vilosas, e lobos da corona suboblongos, quase da altura do ginostégio. Espécies bastante particular dentre aquelas do complexo Metastelma-Ditassa, o que já lhe valeu um gênero monotípico à parte, Stelmation E.Fourn. CEBA (56): Rio de Contas-Catolés e Barra da Estiva-Miguel Calmon; em campos rupestres.

\section{Minaria T.U.P.Konno \& Rapini}

Arbustos, com folhas pequenas (raramente alcançando 1,5 cm compr.) e flores geralmente campanuladas a levemente urceoladas. Com base em estudos filogenéticos (Silva 2008, 2010), Barjonia harleyi e Hemipogon harleyi, espécies endêmicas da Chapada Diamantina deverão ser transferidas para este gênero, que passará a incluir 21 espécies. Descrito há menos de cinco anos, teve suas espécies tratadas em Ditassa na FEM. Todas elas ocorrem no Espinhaço e a maioria está estretitamente associada aos campos rupestres, várias delas microendêmicas (Konno et al. 2006).

18.1. Minaria abortiva (E.Fourn.) Rapini, Taxon 55: 428. 2006.

Guia: Figs. 138-140.

Subarbusto hirsuto, freqüentemente cespitoso, com folhas opostas, eretas, de lâmina cordiforme, e flores de corola alva, creme ou esverdeada; semelhante a $M$. cordata, principalmente em relação ao hábito, pode ser distinguida pelas flores com corola adaxialmente papilosa, passando a setulosa na porção mediana, escavada e glabra na basal, com tubo mais longo (mais de $1 \mathrm{~mm}$ compr.) e lacínias ovadas (mais de $1,5 \mathrm{~cm}$ larg.), lobos da corona ovados, quase da altura do ginostégio. A ênfase dada à semelhança vegetativa entre essas espécies pode estar obscurecendo diferenças florais importantes, possivelmente levando à inclusão de táxons não relacionados em $M$. cordata. $\mathrm{O}$ não reconhecimento taxonômico dessa variação inviabilizou uma definição precisa de sua distribuição geográfica. Com base em uma circunscrição menos inclusiva, foi considerada rara, restrita a São João Del Rey (Rapini et al. 2009). No entanto, segundo a circunscrição adotada aqui, a espécie possui distribuição ampla. AMÉRICA DO SUL: possivelmente Bolívia e Brasil - ES, MG, GO, MS?, MT?, BA, MA?; CEMG* (1): Grão Mogol (Vidal 49 - BHCB); CEBA (13?): Rio de Contas-Palmeiras-Barra da Estiva; em campos rupestres e cerrados, raramente na restinga.

18.2. Minaria acerosa (Mart.) T.U.P.Konno \& Rapini, Taxon 55: 428. 2006.

Guia: Figs. 141-143.
Arbusto a subarbusto, eventualmente volúvel para o ápice dos ramos, hirsuto, com folhas opostas ou verticiladas, patentes, de lâmina oblonga, marcadamente revoluta, e flores de corola geralmente amarelada a creme, com lobos da corona bursiculares, formados por dois segmentos, o externo triangular, mais alto ou quase do tamanho do ginostégio, o interno mais baixo que ele. AMÉRICA DO SUL: Argentina, Bolívia e Brasil - PR, SP, RJ? (Glaziou 1121 - K, P), ES, MG, GO, MT, TO, BA, PI, MA - CEMG (125): Ouro Preto-Grão Mogol, Serra do Cabral; CEBA (15): Caetité-Seabra-Barra da Estiva; em cerrados e campos, mais raramente em caatingas e restingas.

18.3. Minaria bifurcata (Rapini) T.U.P.Konno \& Rapini, Taxon 55: 428. 2006.

Arbusto escabroso, com folhas opostas, patentes, de lâmina elíptica, flores com corona de lobos inteiros na metade basal, bifurcando-se para o ápice em dois segmentos lineares, mais altos que o ginostégio. Conhecida apenas pelo materialtipo. CEMG (1 - rara): Diamantina; campos rupestres.

18.4. Minaria campanuliflora Rapini, Taxon 55: 428. 2006.

Guia: Figs. 144 e 145.

Subarbusto hirsuto com folhas opostas, eretas, de lâmina cordiforme; semelhante a M. abortiva, pode ser distinguida pelas flores conspícuas, com corola de mais de $5 \mathrm{~mm}$ compr., creme passando a esbranquiçada para base ou freqüentemente avermelhada, distintamente glabra adaxialmente. CEMG (5 rara): São Gonçalo do Rio Preto; em campos rupestres.

18.5. Minaria cordata (Turcz.) T.U.P.Konno \& Rapini, Taxon 55: 429. 2006.

Guia: Figs. 146-148.

Subarbusto hirsuto com folhas opostas, eretas, de lâmina cordiforme, e flores de corola alva ou creme, com tubo curto (menos de $1 \mathrm{~mm}$ compr.) e lacínias lanceoladas (menos de 1,5 cm larg.), adaxialmente barbadas na região central e papilosas para as margens, com lobos da corona de segmento externo geralmente linear e mais alto que o ginostégio e o interno diminuto. Brasil - MG, GO, TO, BA - CEBA (19?): CaetitéPiatã e Jacobina; em campos rupestres e cerrados.

18.6. Minaria decussata (Mart.) T.U.P.Konno \& Rapini, Taxon 55: 429. 2006.

Guia: Figs. 149-152.

Subarbustos a arbustos, geralmente cespitosos, ramos hirsutos a vilosos, com folhas geralmente opostas, patentes a obliquamente eretas, de lâmina cordiforme, revoluta, geralmente bulada, hirsuta a pilosa, e flores de corola geralmente amarelada, adaxialmente papilosa a puberulenta, escavada e glabra a partir da porção central das lacínias, com lobos da corona de segmentos lineares, geralmente quase iguais entre si e da altura ou mais altos que o ginostégio. Brasil - ES, MG, BA* - CEMG (153): Ouro Branco-Grão Mogol e Serra do Cabral; CEBA (1): Barra da Estiva (Ribeiro 347 - HUEFS); em campos rupestres, raramente em restinga. 
18.7. Minaria diamantinensis (Fontella) T.U.P.Konno \& Rapini, Taxon 55: 429. 2006.

Guia: Figs. 153-155.

Subarbusto com folhas opostas ou verticiladas, patentes, de lâmina oblonga, marcadamente revoluta, e flores de corola amarelada; assemelha-se a M. acerosa, porém é mais delicada, não superando $20 \mathrm{~cm}$ alt., vegetativamente alvo-tomentulosa, com ramos prostrados, inflorescências unifloras e flores com lobos da corona com os dois segmentos lineares e mais altos que o ginostégio. CEMG (9 - rara): Diamantina; em campos rupestres.

18.8. Minaria ditassoides (Silveira) T.U.P.Konno \& Rapini, Taxon 55: 429. 2006.

Guia: Figs. 156-158.

Subarbusto cespitoso, hirsuto, com folhas opostas, geralmente obliquamente eretas, de lâmina cordiforme, alvo-tomentosa a vilosa abaxialmente, e flores de corola alva, com lobos da corona lanceolados, da altura ou pouco mais altos que o ginostégio, adaxialmente providos de uma prega diminuta na base; assemelha-se a M. cordata, tanto em relação ao hábito quanto em relação à flor, porém diferenciase pelos polinários com caudículos laminares e retos, enquanto naquela espécie eles são lineares e distalmente arqueados. CEMG (143): Serra do Cipó-Rio Pardo de Minas; em campos rupestres.

18.9. Minaria grazielae (Fontella \& Marquete) T.U.P.Konno \& Rapini, Taxon 55: 429. 2006.

Guia: Figs. 159-161.

Arbusto rupícola, cespitoso, escabroso, com folhas opostas, reflexas, de lâmina cimbiforme, e flores solitárias na axila das folhas, de corola alva, urceolada, adaxialmente papilosa no terço apical e pilosa a barbada na metade basal das lacínias, sem corona. CEMG (18 - rara): Diamantina; em campos rupestres.

18.10. Minaria hemipogonoides (E.Fourn.) T.U.P.Konno \& Rapini, Taxon 55: 429. 2006.

Guia: Figs. 162-164.

Arbusto cespitoso, glabro a minutamente escabroso, com folhas helicoidalmente dispostas, obliquamente eretas, de lâmina elíptica, e flores geralmente solitárias, de corola creme, abaxialmente glabra, adaxialmente papilosa, barbada na metade basal, com lobos da corona de segmentos lineares, quase iguais entre si e pouco mais altos que o ginostégio. Após 100 anos sem ter sido coletada, foi encontrada novamente, em 2008, na Serra da Lapa, porção oeste da Serra do Cipó. CEMG (9 - rara): Serra do Cipó; em campos rupestres.

18.11. Minaria inconspicua (Rapini) Rapini, Taxon 55: 429. 2006.

Erva com ramo hirtelo, folhas opostas, eretas ou quase, de lâmina estreitamente lanceolada a linear, glabra ou quase, e flores solitárias, de corola creme, adaxialmente papilosa, barbelada no terço basal das lacínias; semelhante a $M$. polygaloides, pode ser distinguida daquela espécie pelos internós mais longos que as folhas, flores claras, adaxialmente com um tufo de tricomas macios e involutos na base das lacínias. CEMG (5 - rara): Diamantina; em campos rupestres.

18.12. Minaria lourteigiae (Fontella) T.U.P.Konno \& Rapini, Taxon 55: 429. 2006.

Guia: Figs. 165 e 166.

Subarbusto hirsuto, com folhas opostas, eretas, de lâmina cordiforme, flores de corola alva ou creme, adaxialmente papilosa, setulosa na porção basal das lacínias, com lobos da corona largamente ovados, mais baixos que o ginostégio e adaxialmente com uma prega basal; semelhante a $M$. abortiva, pode ser distinguida principalmente pelos entrenós mais compridos que as folhas. Brasil - MT?* (Souza 14174 ESA), GO?* (Irwin 17843 - NY), MG - CEMG (3): Serra do Cabral; em campos rupestres.

18.13. Minaria magisteriana (Rapini) T.U.P.Konno \& Rapini, Taxon 55: 429. 2006.

Guia: Figs. 167 e 168.

Arbusto rupícola, cespitoso, com ramos escabrosos, folhas opostas, verticiladas ou helicoidalmente dispostas, obliquamente eretas, de lâmina oblonga a linear, carenada, glabra, e flores solitárias, de corola alva, adaxialmente papilosa, com tricomas retrorsos na base das lacínias; assemelha-se a $M$. hemipogonoides, porém suas folhas são mais longas (mais de $5 \mathrm{~mm}$ compr.), a corola não é barbada adaxialmente e os lobos da corona possuem o segmento externo subulado, bem mais alto que o ginostégio, e o interno triangular quase da altura dele. CEMG (6 - rara): Serra do Cipó; em campos rupestres.

18.14. Minaria micromeria (Decne.) T.U.P.Konno \& Rapini, Taxon 55: 429. 2006.

Guia: Fig. 169.

Subarbusto cespitoso, escabroso a hirtelo, com folhas opostas, obliquamente eretas, levemente recurvadas, de lâmina oblonga, revoluta ou quase, e flores de corola alva ou creme, adaxialmente papilosa, com lobos da corona de segmento externo mais alto que o ginostégio e interno quase da altura dele; as folhas lembram as de M. acerosa, porém são bem menores (geralmente até $3 \mathrm{~mm}$ compr.). Brasil SP* (Batatais: Regnell III71 - C, K, LE, P, S-2, UPS), MG, GO, MS, BA - CEMG (35): Itabirito-Botumirim e Serra do Cabral; em campos rupestres e cerrados.

18.15. Minaria monocoronata (Rapini) T.U.P.Konno \& Rapini, Taxon 55: 429. 2006.

Erva a subarbusto decumbente, com ramos pubescentes, folhas opostas, patentes, de lâmina ovada a lanceolada, levemente cimbiforme, esparsamente ciliada, e flores de corola alva ou creme-acastanhada, adaxialmente papilosa, barbelada na metade basal das lacínias. CEMG (5 - rara): Serra da Moeda e Itabirito; em canga. 
18.16. Minaria parva (Silveira) T.U.P.Konno \& Rapini, Taxon 55: 429. 2006.

Guia: Figs. 170-172.

Subarbusto cespitoso, com ramos hirsutos, folhas opostas, eretas, de lâmina triangular, revoluta, glabrescente, e flores de corola creme a esverdeada, adaxialmente papilosa, barbelada a barbada na base das lacínias, com lobos da corona quase da altura do ginostégio, adaxialmente com uma prega na base; assemelha-se a $M$. abortiva, podendo ser distinguida pelo tamanho, raramente ultrapassando $15 \mathrm{~cm}$ alt. CEMG (30): Serra do Caraça, Serra do Cipó-São Gonçalo do Rio Preto, Botumirim* (Ribeiro et al. 189 - HUEFS); em campos rupestres.

18.17. Minaria polygaloides (Silveira) T.U.P.Konno \& Rapini, Taxon 55: 429. 2006.

Guia: Figs. 173-175.

Erva a subarbusto com ramos hirsutos, folhas opostas, obliquamente eretas, de lâmina lanceolada, mais longa que os internós, glabra ou quase, e flores solitárias, de corola rosada, adaxialmente papilosa, com tricomas patentes a retrorsos na base das lacínias. CEMG (15 - rara): Caeté*? (Serra do Córrego das Congonhas: Magalhães 2640 - BHCB) e Serra do Cipó; em campos rupestres.

18.18. Minaria refractifolia (K.Schum.) T.U.P.Konno \& Rapini, Taxon 55: 430. 2006.

Guia: Figs. 176-178.

Arbusto rupícola, cespitoso, com ramos pubescentes, folhas opostas, reflexas, de lâmina sublanceolada, cimbiforme, adaxialmente glabra, abaxialmente esparsamente pubescente, flores de corola creme-esverdeada, adaxialmente papilosas, passando a puberulenta para a base, com lobos da corona de segmentos oblongos a triangulares, quase da altura do ginostégio. CEMG (31 - rara): Serro-São Gonçalo do Rio Preto; em campos rupestres.

18.19. Minaria semirii (Fontella) T.U.P.Konno \& Rapini, Taxon 55: 430. 2006.

Guia: Figs. 179-181.

Arbusto rupícola, cespitoso, com ramos escabrosos, folhas opostas, geralmente patentes, de lâmina cordiforme, glabra ou escabrosa, e flores solitárias ou em pares, na axila das folhas, de corola creme, esbranquiçada a rósea para a base, adaxialmente papilosa no terço apical, barbada a pilosa na metade basal das lacínias, sem corona. CEMG (6 - rara): Serra do Cipó; em campos rupestres.

\section{Nephradenia Decne.}

Inclui cerca de dez espécies sul-americanas. Apresenta afinidades principalmente com Minaria, Barjonia e Hemipogon, mas sua circunscrição e as relações filogenéticas de suas espécies dentre as Metastelmatinae ainda não estão resolvidas (Silva 2010). Reúne ervas eretas e trepadeiras, glabras ou quase, com folhas estreitas, acerosas, lineares ou filiformes.

19.1. Nephradenia acerosa Decne. in A.DC., Prodr. 8: 604. 1844.

Guia: Figs. 182 e 183.

Erva com folhas lineares, reconhecida pelas flores atropurpúreas, com corola campanulada a subglobosa, adaxialmente papilosa nas lacínias, e lobos da corona inconspícuos. Brasil - MG, GO, MT, TO* (Porto Nacional: Alves 2263 - CEPEC, SPF, UFP), BA, MA* (Carolina: Pires 2270 - IAN), PA* (Alto Tapajós: Anderson 10901 - HB, IAN) - CEMG (8): Diamantina e Serra do Cabral; em campos, geralmente associada a solos pouco drenados, e cerrados, freqüentemente em veredas.

19.2. Nephradenia asparagoides (Decne.) E.Fourn in Mart. \& Eichler, Fl. bras. 6(4): 330. 1885.

Guia: Figs. 184 e 185.

Trepadeira com folhas lineares a filiformes, freqüentemente agrupadas em fascículos, e flores de corola esverdeada, rotácea, com lacínias recurvadas, e corona alva, de lobos inteiros na porção basal e bífidos na apical. Brasil - GO, BA - CEBA (12): Rio de Contas (Paramirim), Macaúbas e Morro do Chapéu; em caatingas e campos rupestres.

\section{Orthosia Decne.}

Inclui cerca de 40 espécies, desde a Argentina até a Flórida, com centro de diversidade no Brasil, especialmente na Região Sudeste (Liede-Schumann \& Meve 2008). Está proximamente relacionada a Jobinia, que, juntamente com espécies tradicionalmente incluídas em 'Cynanchum', compõem as Orthosiinae (Liede-Schumann et al. 2005). São trepadeiras geralmente glabras ou quase, freqüentemente com flores decíduas ou reduzidas na região florífera e com frutos caracterizados pelo desenvolvimento dos dois folicários.

20.1. Orthosia scoparia (Nutt.) Liede \& Meve, Novon 18: 207. 2008.

Guia: Fig. 186.

Trepadeira glabra ou quase, com folhas de lâmina oblonga a linear, reduzidas ou ausentes na região florífera, e flores diminutas (até $3 \mathrm{~mm}$ compr.), de corola geralmente vinácea, eventualmente esverdeada, glabra, com corona aneliformes, levemente lobada. Na FEM, foi tratada em Metastelma. Neotropical, ocorrendo em Porto Rico, Caribe, Sudeste dos Estados Unidos e na AMÉRICA DO SUL: Argentina, Paraguai, Peru, Colômbia, Venezuela e Brasil - RS, SC, PR, SP, RJ, ES, MG, CE* (Maranguape: Martins s.n. - EAC 9050) - CEMG (23): Ouro Preto-Serra do Cipó; principalmente em florestas montanas. 


\section{Oxypetalum R.Br.}

Com cerca de 125 espécies, é o maior gênero em Oxypetalinae, e o mais diverso no Brasil. A maioria das espécies está concentrada no norte da Argentina e nas Regiões Sul e Sudeste do Brasil; o número de espécies decresce para o norte, com $O$. cordifolium e $O$. capitatum alcançando o México e os Estados Unidos, respectivamente (Farinaccio 2007). Com eventuais exceções, pode ser reconhecido pela combinação de flores com corola de lacínias geralmente lanceoladas a lineares, polinários com dente córneo lateral nos caudículos e ápice do ginostégio rostrado, formando um apêndice em forma de estilete.

21.1. Oxypetalum appendiculatum Mart., Nov. Gen. sp. pl. 1: 48; t. 30. 1824.

Guia: Figs. 187-189.

Trepadeira com flores de corola e corona cremeesverdeadas, freqüentemente vináceas para a base, lacínias da corola eretas a recurvadas, lobos da corona escamiformes e apêndice do ginostégio vináceo, bífido acima da porção mediana; diagnosticada pela presença de polinários com apêndices hialinos no ápice do retináculo. AMÉRICA DO SUL: Uruguai, Argentina, Paraguai, Bolívia e Brasil - RS, SC, PR, SP, RJ, MG, MS, MT - CEMG (81): Ouro PretoDiamantina; em orla de matas, campos e cerrados.

21.2. Oxypetalum arachnoideum E.Fourn. in Mart. \& Eichler, Fl. bras. 6(4): 272. 1885.

Trepadeira com flores de corola esverdeada, lacínias patentes a reflexas, lobos da corona vináceos, creme nas margens, escutiformes, adaxialmente carunculados, e apêndice do ginostégio bífido a partir da região mediana; reconhecida pelas lacínias longas ( $c a .3 \mathrm{~cm}$ compr.), quase filiformes. Brasil - SP, RJ, MG, BA - CEMG (1): Monte Azul; CEBA (3): Caetité e Catolés; geralmente em carrascos.

21.3. Oxypetalum banksii R.Br. ex Schult., Syst. veg. 6: 91. 1820.

Guia: Figs. 190 e 191.

Trepadeira com flores de corola creme-esverdeada, vinácea para base, lacínias reflexas, torcidas distalmente, lobos da corona creme, espatulados, e apêndice do ginostégio vináceo, bífido a partir da região mediana. Brasil - RS, PR, SC, SP, MG, RJ, ES, BA, SE - CEMG (2): Caeté; CEBA (1): Jacobina; geralmente em restinga, raramente adentrando por matas secundárias e refúgios de floresta atlântica.

21.4. Oxypetalum capitatum Mart., Nov. Gen. sp. pl. 1: 50. 1824.

Planta ereta até $40 \mathrm{~cm}$ alt., com flores de corola creme a verde-acastanhada, lacínias recurvadas, torcidas, lobos da corona alvos, ovados, bífidos no ápice, e apêndice do ginostégio fendido no quinto apical. AMÉRICA DO SUL: Argentina, Paraguai, Colômbia, Venezuela, Guiana, Suriname e Brasil - RS, SC, PR, SP, MG, GO, MS, MT, BA,
PE, PA, AM - CEMG (6): Ouro Preto-Caeté, Diamantina* (Melo Barreto 10024 - BHCB) e Grão Mogol* (Lima 1024 - RB); CEBA (2): Rio de Contas e Jacobina; em campos e cerrados.

21.5. Oxypetalum erectum Mart., Nov. Gen. sp. pl. 1: 50. 1824.

Guia: Figs. 192-195.

Planta ereta, até $70 \mathrm{~cm}$ alt., com flores vistosas, de corola abaxialmente castanho-avermelhada, eventualmente esverdeada, adaxialmente alva ou creme, levemente vinácea para base, lobos da corona alvoesverdeados, oblongos a escamiformes, adaxialmente corniculados, e apêndice do ginostégio vináceo, bífido a partir do terço basal, mediano ou superior. AMÉRICA DO SUL: Bolívia e Brasil - RS, SC, PR, SP, MG, BA, GO, MT, RO - CEMG (74): Ouro Branco-Caeté, Serra do Cipó* (Rapini 1602 - HUEFS), Diamantina-Grão Mogol; em campos e cerrados.

21.6. Oxypetalum erostre E.Fourn. in Mart. \& Eichler, F1. bras. 6(4): 265.1885 .

Guia: Figs. 196 e 197.

Trepadeira com flores de corola esverdeada a creme, lacínias reflexas, torcidas, lobos da corona amareloesverdeados, depressamente ovados, e apêndice do ginostégio alaranjado, curto e cônico. Brasil - MG, BA - CEMG (14): Belo Horizonte-Diamantina e Botumirim* (Forzza 3800 HUEFS, SPF); CEBA (14): Rio de Contas-Morro do Chapéu e Ibicoara; em campos rupestres, carrascos e orla de florestas estacionais e vegetações perturbadas.

21.7. Oxypetalum foliosum Mart., Nov. Gen. sp. pl. 1: 50. 1824.

Guia: Figs. 198 e 200.

Planta ereta, até $1 \mathrm{~m}$ alt., com flores de corola alva a esverdeada, lacínias eretas a recurvadas, torcidas, lobos da corona róseos, oblongos a escamiformes, freqüentemente imbricados, adaxialmente carunculados, e apêndice do ginostégio alvo, bífido a partir da porção mediana. Brasil SC, PR, SP, RJ, MG, MT - CEMG (29): Ouro Preto-Datas; em campos e cerrados.

21.8. Oxypetalum glabrum (Decne.) Malme, Ark. Bot. 21A(3): 29. 1927.

Guia: Figs. 201 e 202.

Trepadeira com flores de corola e corona cremeesverdeadas, lacínias da corola patentes, torcidas, lobos da corona escamiformes a oblongo-emarginados, adaxialmente corniculados, e apêndice do ginostégio alvo, passando a vináceo para a base, ciatiforme ou bilobado no ápice; semelhante a $O$. insigne, distingue-se pelo indumento menos denso em toda a planta, incluindo flores e frutos, e pelos polinários com retináculo linear, enquanto naquela espécie o retináculo é oblongo. Brasil - RS* (São Francisco de Paula: Rambo s.n. - PACA 49410), SC, PR, SP, RJ, MG - CEMG 
(21): Ouro Preto - São Gonçalo do Rio Preto; típica de topos de morros, ocorrendo nos afloramentos rochosos e na beira de florestas montanas.

21.9. Oxypetalum harleyi (Fontella \& Goyder) Farinaccio, Neodiversity 3: 20: 2008.

Guia: Fig. 203.

Trepadeira com flores de corola, corona e apêndice do ginostégio vináceos a atropurpúreos, lacínias da corola patentes, torcidas distalmente, lobos da corona flabeliformes e apêndice do ginostégio bífido acima da região mediana. Brasil - BA, SE? (Simão Dias: Viana 1524 - ASE), PE? (São Lourenço da Mata: Andrade-Lima 11 - IPA), PB? (São Gonçalo: Luetzelburg s.n. - IPA) - CEBA (7): Lençóis, Morro do Chapéu-Senhor do Bonfim; em caatingas e matas sazonais.

21.10. Oxypetalum insigne (Decne.) Malme, Ark. Bot. 21A(3): 31. 1927.

Guia: Fig. 204

Trepadeira com flores de corola creme-esverdeada, lacínias patentes a recurvadas, levemente torcidas, lobos da corona alvos, vináceos para a base, oblongo-emarginados, adaxialmente corniculados, e apêndice do ginostégio ciatiforme, bilobado ou bicorniculado no ápice. Brasil - RS, SC, PR? (Bocaiúva: Barbosa 614 - SPF), SP, RJ, MG CEMG (27): Ouro Preto-Serra do Cipó; orla de matas.

21.11. Oxypetalum jacobinae Decne. in A.DC., Prodr. 8: 584. 1844.

Trepadeira com flores de corola, corona e apêndice do ginostégio geralmente alvos a creme, lacínias da corola eretas ou quase, torcidas, lobos da corona oblongos, adaxialmente corniculados, e apêndice do ginostégio bífido a partir da porção mediana ou abaixo dela. Brasil - MG, RJ, BA - CEMG (20): Ouro Preto-Diamantina; CEBA (4): Caetité-Catolés e Jacobina; em capões e matas de galeria.

21.12. Oxypetalum lineare E.Fourn. in Mart. \& Eichler, Fl. bras. 6(4): 283. 1885.

Planta ereta, $c a .25 \mathrm{~cm}$ alt., com flores de corola cremeacastanhada e lacínias patentes, torcidas, lobos da corona subquadrangulares, bifurcados em dois lóbulos subulados, e apêndice do ginostégio cilíndrico a clavado; reconhecida prontamente pelas folhas lineares. Na FEM, foi erroneamente identificada como O. aequaliflorum E.Fourn. AMÉRICA DO SUL: Paraguai e Brasil - RS, SC, PR, SP, RJ, MG, GO CEMG (2): Diamantina; em campos e cerrados.

21.13. Oxypetalum martii E.Fourn. in Mart. \& Eichler, Fl. bras. 6(4): 280. 1885.

Planta ereta, $c a .50 \mathrm{~cm}$ alt., com flores de corola verdeacastanhada, lacínias patentes a reflexas, lobos da corona esverdeados, ovados, bífidos a partir da porção mediana, apêndice do ginostégio alvo, coroniforme no ápice; semelhante a $O$. capitatum, distingue-se pelas flores menores (lacínias da corola até 4,5 $\mathrm{mm}$ compr.), e pelos polinários com caudículos sem dente lateral. Brasil - RS, PR, SP, MG, GO, MS, MT, BA - CEMG* (1): São Gonçalo do Rio Preto (Viana 1248 - BHCB); CEBA (1): Jacobina; em campos.

21.14. Oxypetalum minarum E.Fourn. in Mart. \& Eichler, Fl. bras. 6(4): 258; t. 73, f. 1.1885.

Guia: Figs. 205 e 206.

Trepadeira com flores de corola creme-esverdeada, com lacínias patentes, levemente torcidas, lobos da corona alvos, escamiformes, bilobulados, e apêndice do ginostégio alvo, bífido até a base; semelhante a $O$. montanum, distinguese prontamente daquela espécie pelo ápice do ginostégio completamente dividido. Brasil - MG - CEMG (32): Ouro Branco-Serra do Caraça; em campos e brejos.

21.15. Oxypetalum montanum Mart., Nov. Gen. sp. pl. 1: 49.1824

Guia: Figs. 207-209.

Trepadeira com flores de corola creme-esverdeada, lacínias patentes, espiraladas, lobos da corona alvos, ovados, eventualmente tridentados ou arredondados e recurvados no ápice, adaxialmente carunculados, e apêndice do ginostégio alvo a vináceo, bífido a partir do terço basal ou mediano. CEMG (73): Serra do Cipó-Itacambira e Serra do Cabral; CEBA (10): Rio de Contas e Catolés; campos rupestres e capões, geralmente associados a solos encharcados.

21.16. Oxypetalum pachyglossum Decne. in A.DC., Prodr. 8: 585. 1844

Guia: Figs. 210 e 211.

Trepadeira com flores de corola esverdeada, com traços vináceos abaxialmente, lacínias recurvadas, lobos da corona alvos, ovado-fendidos, e apêndice do ginostégio alvo, cônico; destaca-se pelas flores pequenas, com lacínias curtas, ovadas a triangulares, polinários com caudículos desprovidos de dente lateral e apêndice do ginostégio curto e incluso. Brasil - SC, PR, SP, RJ, MG, BA, PE - CEMG (29): Ouro Preto-Caeté; geralmente em restingas e campos brejosos.

21.17. Oxypetalum pachygynum Decne. in A.DC., Prodr. 8: 583.1844.

Guia: Figs. 213 e 214.

Trepadeira com flores de corola creme-esverdeada, geralmente vinácea abaxialmente, lacínias patentes a recurvadas, levemente torcidas, lobos da corona creme, subcuneiformes, e apêndice do ginostégio vináceo, bífido a partir do terço superior. AMÉRICA DO SUL: Paraguai e Brasil - PR, SP, RJ, MG, GO, MT, MS - CEMG (7): Ouro Preto-Serra do Cipó e Serra do Cabral; geralmente em brejos e veredas.

21.18. Oxypetalum patulum E.Fourn. in Mart. \& Eichler, Fl. bras. 6(4): 278. 1885.

Subarbusto $c a .20 \mathrm{~cm}$ alt., com flores de corola alva e lacínias obliquamente eretas, torcidas, lobos da corona claros, suboblongos, com uma prega adaxialmente, e apêndice do 
ginostégio bífido a partir da região mediana. Semelhante a $O$. foliosum, porém menores (não atingindo $50 \mathrm{~cm}$ alt.), procumbentes, com inflorescências paucifloras (até 4 flores). Considerada rara (Rapini et al. 2009), tem aqui sua distribuição ampliada. Brasil - $\mathrm{MG}$ - $\mathrm{CEMG}^{*}$ (1): Serra do Cipó (Barreto 8527 - HUEFS); em campo.

21.19. Oxypetalum pilosum Gardner, London J. Bot. 1: 539. 1842.

Trepadeira com flores de corola esverdeada, com lacínias patentes, levemente torcidas, lobos da corona deltóides e apêndice do ginostégio vináceo, bífido no terço apical. Brasil - SP, RJ, ES, MG - CEMG? (2): Mariana e Sabará; geralmente em inselbergues na Mata Atlântica.

21.20. Oxypetalum polyanthum (Hoehne) Rapini, Bol. Bot. Univ. São Paulo 21(2): 278. 2003.

Guia: Figs. 215 e 216.

Planta ereta, raramente volúvel, até $60 \mathrm{~cm}$ alt., com flores de corola abaxialmente vinácea, adaxialmente ocre, com lacínias patentes a reflexas, levemente revolutas, lobos da corona alvos, bilobulados, adaxialmente cristados, os lóbulos oblongos a sublunados, e apêndice do ginostégio esverdeado passando a vináceo para a base, bífido a partir da porção mediana; como em $O$. strictum e $O$. warmingii, também apresenta apêndice apical dos estames exclusos, diferindo de ambas pelos polinários com retináculo menor (até $1,5 \mathrm{~mm}$ compr.). CEMG (31): Serra do Cipó-São Gonçalo do Rio Preto; em campos rupestres.

21.21. Oxypetalum rusticum Rapini, Novon 12: 385; f. 1. 2002.

Guia: Figs. 217-219.

Trepadeira com flores de corola creme-esverdeada, vinácea para a base, lacínias patentes, torcidas, lobos da corona alvos, oblongo-fendidos, e apêndice do ginostégio alvo, coroniforme no ápice, levemente bilobado; semelhante a $O$. insigne, distingue-se pelos ramos lanosos, e polinários com retináculo maior (pelo menos 2,5 mm compr.). CEMG (11): Diamantina; em capões entre pedras.

21.22. Oxypetalum strictum Mart., Nov. Gen. sp. pl. 1: 50. 1824 .

Guia: Figs. 220-222.

Planta ereta, até $80 \mathrm{~cm}$ alt., passando a volúvel para o norte da distribuição da espécie, com flores de corola abaxialmente ocre, adaxialmente esverdeada, alvacenta, lacínias reflexas, lobos da corona alvos, bilobulados, adaxialmente cristados, os lóbulos lunados, e apêndice do ginostégio vináceo, esverdeado no ápice, bífido geralmente a partir da região mediana; como em $O$. polyanthum e $O$. warmingii, também apresenta apêndice apical dos estames exclusos, diferindo da primeira pelos polinários com retinaculo maior (geralmente mais de $1,8 \mathrm{~mm}$ compr.) e da segunda pelas flores com lacínias da corola reflexas e mais curtas (até 1,5 cm compr.). Brasil - SP, MG, BA - CEMG (172): Ouro Branco-Grão
Mogol; CEBA (18): Caetité-Palmeiras e Ibicoara; geralmente em campos rupestres.

21.23. Oxypetalum warmingii (E.Fourn.) Fontella \& Marquete, Bol. Bot. Mus. Munic. 1: 2. 1971.

Guia: Figs. 223 e 224.

Trepadeira com flores de corola ocre, freqüentemente avermelhada para a base, lacínias eretas, lobos da corona bilobulados, adaxialmente cristados, os lóbulos retangulares, divaricados, e apêndice do ginostégio vináceo, completamente bífido em ramos filiformes; como em $O$. strictum e $O$. polyanthum, também apresenta apêndice apical dos estames exclusos, diferindo facilmente delas pelas flores com corola de lacínias longas (pelo menos $2 \mathrm{~cm}$ compr.) e eretas. Brasil - PR, SP, MG, GO - CEMG (63): Belo Horizonte-Botumirim e Serra do Cabral; em campos rupestres e cerrados.

21.24. Oxypetalum wightianum Hook. \& Arn., J. Bot. (Hooker) 1: 288. 1834.

Guia: Figs. 225-227.

Trepadeira com flores de corola roxa, passando a amarelada em direção ao ápice das lacínias, lacínias reflexas, lobos da corona amarelos, trilobulados, adaxialmente carunculados, e apêndice do ginostégio vináceo, bifurcado a partir da região mediana; também diagnosticada pelos frutos com pericarpo verrucoso. AMÉRICA DO SUL: Paraguai e Brasil - RS, SC, PR, SP, RJ, ES* (Castelo: Kollmann 10553 - RB), MG, MS* (Bodoquena: Hatschbach 74765 - HUEFS, MBM) - CEMG (35): Ouro Preto-Serra do Cipó; em matas e capoeiras, geralmente associada a riachos.

\section{Peplonia Decne.}

Exclusivamente brasileiro, inclui seis espécies, com centro de diversidade no Rio de Janeiro (Rapini et al. 2004). São trepadeiras glabras ou quase, com folhas de lâmina coriácea, inflorescências axilares e opostas, e flores com corola alva ou creme e corona geralmente de lobos simples, mais também duplos, com lobos externamente fundidos quase até o ápice e os segmentos internos livres entre si. Inclui Gonioanthela Malme em sua sinonímia e deverá incluir Macroditassa também (Silva 2010).

22.1. Peplonia organensis (Malme) Fontella \& Rapini, Kew Bull. 59: 537. 2004.

Guia: Figs. 228 e 229.

Suas folhas tornam-se castanhas quando herborizadas e a nervação é inconspícua; semelhante a $P$. axillaris (Vell.) Fontella \& Rapini, da qual se diferencia pelos lobos da corona suboblongos e inteiros, enquanto naquela espécie eles são geralmente espatulados e crispados para o ápice. Na FEM, foi tratada como G. hilariana (E.Fourn.) Malme. Brasil - SP, RJ, MG - CEMG (32): Ouro Preto-Gouveia; geralmente em borda de capões. 


\section{Schubertia Mart.}

Com cerca de cinco espécies sul-americanas, pertence a Gonolobinae e apresenta afinidade com Macroscepis Kunth (Krings et al. 2008), gênero concentrado principalmente na América Central, alcançando o México. São trepadeiras com ramos hirsutos, folhas velutinas, flores grandes (mais de $2 \mathrm{~cm}$ compr.), corona corolina e frutos costados ou equinados.

23.1. Schubertia grandiflora Mart., Nov. Gen. sp. pl. 1: 57. 1824

Guia: Figs. 230-232.

Reconhecida pelas flores grandes (mais de $3 \mathrm{~cm}$ compr.), de corola alva, esverdeada para a base, urceolada, com tubo mais longo que as lacínias, adaxialmente com tricomas longos próximo à fauce, e frutos equinados. AMÉRICA DO SUL: Argentina, Paraguai, Bolívia e Brasil - SP, RJ, MG, GO, MT, MS, TO, BA, PB, CE, PI, MA, PA, AM, RO - CEBA (1): Rio de Contas; em cerrados, carrascos, capoeiras e matas secas, freqüente em beira de estradas.

23.2. Schubertia morilloana Fontella, Pabstia 5(1): 2 ; t. 2. 1994.

Guia: Figs. 233-235.

Reconhecida pelas flores de corola geralmente verde, adaxialmente glabra, e pelos frutos costados. Brasil $-\mathrm{MG}^{*}$ (Medina: Hatschbach 52716 - MBM, SPF), BA, PB* (Pilar: Andrade-Lima 52-1169 - IPA) - CEBA (18): Licínio de Almeida-Catolés e Macaúbas; geralmente em caatingas e vegetações antropizadas.

23.3. Schubertia multiflora Mart., Nov. Gen. sp. pl. 1: 56; t. 33.1824

Guia: Figs. 236 e 237.

Vegetativamente semelhante a $S$. grandiflora, pode ser distinguida pelas flores menores (menos de 2,5 cm compr.), com lacínias da corola mais longas que o tubo, e pelos frutos costados; as flores lembram aquelas de $S$. morilloana, porém a corola é alva, eventualmente amarelada na fauce. Brasil BA, SE, PE, PB, CE, PI, RN - CEBA (8): Andaraí-Morro do Chapéu; em caatingas, matas secas ou antropizada, eventualmente em afloramentos rochosos.

\section{Tassadia Decne.}

Inclui cerca de 25 espécies, com centro de diversidade no norte da América do Sul, estando mais da metade das espécies representadas na Venezuela. Apesar de morfologicamente semelhantes a Metastelmatinae, estudos filogenéticos com dados moleculares indicam que o gênero se encontra possivelmente mais relacionado a Gonolobinae ou Oxypetalinae (Liede-Schumann et al. 2005). São trepadeiras com folhas geralmente elípticas a ovadas e flores pequenas (ca. $2 \mathrm{~mm}$ compr.), em cimeiras geralmente arranjadas em ramos áfilos ou bracteosos.
24.1. Tassadia burchellii E.Fourn. in Mart. \& Eichler, Fl. bras. 6(4): 230. 1885.

Folhas geralmente castanhas após herborizadas, flores em glomérulos multifloros (com mais de 10 flores), de corola alva, campanulada, adaxialmente tomentosa, vilosa na porção central das lacínias, e lobos da corona subquadrangulares, sinuosamente prolongados medianamente acima do ginostégio. Brasil - GO, MT, MS* (Rio Verde: Silva 5404 - HUEFS, MBM), TO* (Dianópolis: Cavalcanti 3383 HUEFS), BA*, CE* (Crato: Plowman 12746 - CEPEC, EAC) - CEBA (2): Rio de Contas (Livramento do Brumado: Queiroz 3661 - HUEFS); geralmente em matas ciliares.

24.2. Tassadia propinqua Decne. in A.DC., Prodr. 8: 579. 1844.

Reconhecida pelas folhas mais claras no material herborizado, geralmente esverdeadas ou amareladas, flores pediceladas, em cimeiras paucifloras (menos de 10 flores), de corola creme, adaxialmente puberulenta, e com lobos da corona trilobulados, mais baixos que o ginostégio, o lóbulo mediano depressamente ovado, flanqueado por dois lóbulos digitiformes. AMÉRICA DO SUL: Colômbia, Venezuela, Guiana, Suriname e Brasil - ES* (Linhares: Pereira 1097 ALCB, CEPEC), MG, GO, MT, TO, BA, MA, PA, AM, AP, RR - CEMG (7): Diamantina e Serra do Cabral; em restingas e matas ciliares.

\section{Discussão}

\section{Esforço amostral ao longo do Espinhaço}

O levantamento das Asclepiadoideae da Cadeia do Espinhaço amplia em mais de $75 \%$ os registros incluídos na FEM (Rapini 2000a, Rapini et al. 2001). Esse aumento se deve à adição de 844 registros da porção baiana e mais de 600 coletas realizadas na porção mineira somente nesta última década, além da complementação de materiais de diversos herbários visitados desde 2002 (veja Material e Métodos). O número de coletas ao longo do Espinhaço tem crescido de maneira contínua (Fig. 2). No início, ele era sustentado basicamente por levantamentos na porção mineira; excluindo as coletas de Martius e Blanchet, ainda no século XIX, os levantamentos na porção baiana tiveram início apenas na década de 1970, com os esforços de Howard S. Irwin e Raymond M. Harley. Nas últimas duas décadas, no entanto, as coletas no Espinhaço da Bahia já correspondem a mais de $50 \%$ daquelas realizadas no Espinhaço de Minas no mesmo período, e, atualmente, elas já totalizam cerca de 1/4 do total de registros de Asclepiadoideae do Espinhaço.

Apesar do incremento das coletas na porção baiana do Espinhaço, o esforço global, avaliado através do número de coletas por espécie, no Espinhaço de Minas é praticamente o dobro daquele na Bahia (média de 25,5 e 12,8 coletas/espécie, respectivamente). Enquanto esse tipo de desigualdade tem sido amenizado entre as regiões do Espinhaço de Minas, levando à complementação das floras regionais e preenchendo 


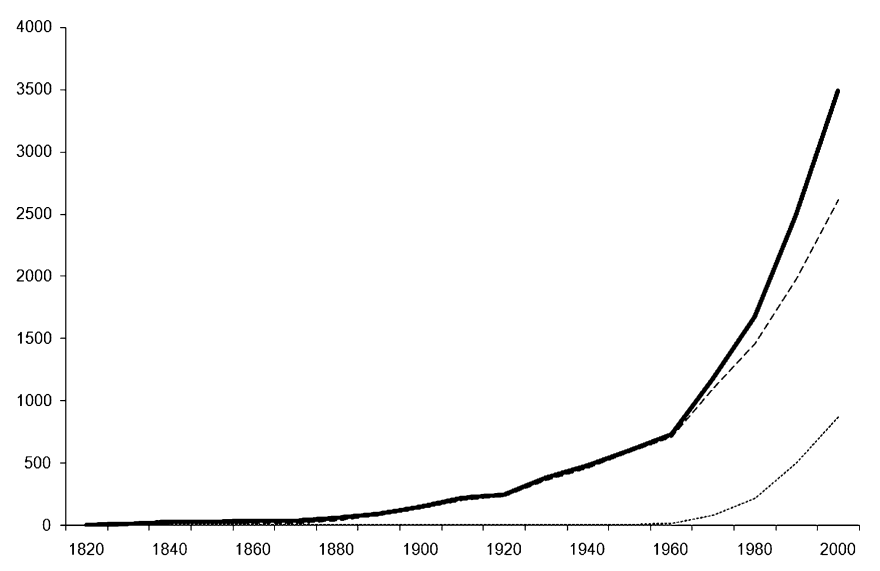

Fig. 2. Evolução do número de coletas na Cadeia do Espinhaço. Curva em negrito: número total de coletas no Espinhaço; curva tracejada: número de coletas na porção mineira; curva pontilhada: número de coletas na porção baiana.

importantes lacunas na distribuição das espécies, os esforços de amostragem no Espinhaço da Bahia ainda são nitidamente discrepantes entre suas regiões. As coletas estão concentradas principalmente na porção sul da Chapada Diamantina, direcionadas à preparação das floras de Mucugê (Harley \& Simmons 1986), na sua vertente oriental, e de Rio de Contas (Stannard 1995) e Catolés (Zappi et al. 2003), na sua vertente ocidental, além do levantamento na Chapadinha e Pai Inácio (Guedes \& Orge 1998), pequena área na zona central do bloco. Na porção Norte do Espinhaço, a preparação da flora de Morro do Chapéu, iniciada nos últimos anos, vem incrementando o conhecimento florístico daquela região, porém muito pouco tem sido feito no Sul do Espinhaço da Bahia. Essa região liga o Norte do Espinhaço de Minas com a Chapada Diamantina e suas espécies estão todas representadas em outras regiões da Cadeia, incluindo Barjonia chloraeifolia, endêmica dos campos rupestres do Espinhaço, e que evidencia a relação histórica de sua flora com as das demais regiões da Cadeia. Atualmente, no entanto, ela conta com menos de 50 coletas de Asclepiadoideae, uma média inferior a quatro coletas por espécie e mais da metade de suas espécies estão representadas por um único registro.

\section{Atualizando e complementando a Flora do Espinhaço}

Em comparação com a FEM (Rapini 2000a, Rapini et al. 2001, 2002), esta lista apresenta como novidades o gênero Minaria, cujas espécies foram tratadas em Ditassa; Gonioanthela Malme sinonimizada em Peplonia, tendo $G$. hilariana sob a combinação P. organensis; Metastelma scoparium Nutt. transferida para Orthosia e Metastelma burchellii (Hook. \& Arn.) Rapini e Macroditassa melantha (Silveira) Rapini para Ditassa. Blepharodon nitidum foi incluída na sinonímia de B. pictum e Gonolobus selloanus na de G. parviflorus. Minaria abortiva e Oxypetalum capitatum foram encontradas em Grão Mogol, adicionando duas espécies àquela flora (Rapini et al. 2003a), e Barjonia laxa, Blepharodon lineare, Cynanchum roulinioides, Ditassa laevis, Macroditassa macrophylla, Oxypetalum erectum, $O$. patulum e $O$. wightianum foram registradas na Serra do Cipó, acrescentando mais oito espécies para aquela flora (FontellaPereira et al. 1995; veja também Rapini et al. 2002) e uma ( $O$. patulum) para o Espinhaço como um todo. Ditassa mucronata, Minaria campanuliflora e Oxypetalum martii foram coletadas em São Gonçalo do Rio Preto, no Planalto de Diamantina, localidade que não havia sido explorada até aquela época; a primeira atinge ali seu limite norte de distribuição e as duas últimas representam ocorrências novas para o Espinhaço. Ainda no Planalto de Diamantina, foi adicionada Ditassa glazioui, D. pohliana, Matelea pedalis e Oxypetalum capitatum; as duas primeiras atingindo ali seu limite sul de distribuição no Espinhaço. Ditassa hispida foi registrada no Sul do Espinhaço e D. lenheirensis no Norte do Espinhaço de Minas. Minaria parva foi encontrada em Botumirim, tendo sua distribuição alcançado o Norte do Espinhaço de Minas, enquanto $M$. decussata foi encontrada em Barra da Estiva, sendo a primeira coleta da espécie no Estado da Bahia. Foram registradas, também, Jobinia connivens no Sul do Espinhaço, e Matelea nigra no Norte do Espinhaço de Minas. Três espécies tiveram sua identificação corrigida: Ditassa myrtilloides para D. leonii, Marsdenia macrophylla para $M$. hilariana e Oxypetalum aequaliflorum para O. lineare; a primeira descrita após a publicação da FEM.

Dois gêneros e cinco espécies de ocorrência duvidosa no Espinhaço foram excluídos da lista: Ditassa banksii R.Br. ex Schult., Macroscepis selloana E.Fourn., Oxypetalum regnellii (Malme) Malme, Peplonia asteria (Vell.) Fontella \& E.A.Schwarz e Petalostelma calcaratum (Decne.) Fontella. Os tipos de Macroscepis selloana e Petalostelma calcaratum foram coletados em Sabará, 'termo que abrangia extensão imensa, e compreendia um sem número de arraiais' (Barbosa 1995, p. 291), e acrescentariam dois gêneros ao levantamento. Todavia, como são espécies características de matas e caatingas fora do Espinhaço, não tendo sido encontradas em nenhuma parte da Cadeia, não foram consideradas neste levantamento. Peplonia asteria e Ditassa banksii (esta última incluída na FEM), também referidas por Hoehne (in sched.) a Sabará, foram excluídas da lista pela mesma razão. Finalmente, um espécime de Glaziou (20413a p.p. - P) identificado como Oxypetalum regnellii (Malme) Malme encontra-se entre uma coleção de $O$. appendiculatum de Ouro Preto e deve ter sido misturado, tratando-se possivelmente de um engano.

Ao todo, foram registradas 108 espécies no Espinhaço de Minas ( $c a .80 \%$ da flora do Espinhaço), aumentando em cerca de $10 \%$ o número apontado para a região há menos de uma década (Rapini et al. 2001, 2002). As espécies adicionadas foram Barjonia laxa, Fisheria stellata, Jobinia connivens, Macroditassa grandiflora, M. macrophylla, Minaria abortiva, M. campanuliflora, Oxypetalum martii, O. patulum e Matelea nigra; enquanto, Peplonia asteria foi retirada. No Espinhaço da Bahia, foram registradas 66 espécies ( $c a$. 50\% da flora do Espinhaço); dessas, 41 (ca. 30\%) espécies também 
ocorrem na porção mineira, acrescentando a este tratamento, além do gênero Schubertia, 25 espécies: Barjonia glazioui, 'Barjonia' harleyi, 'Blepharodon' manicatum, 'Cynanchum' morrenioides, Ditassa dardanoi, D. oxyphylla, D. rotundifolia, 'Hemipogon' harleyi, Jobinia lindbergii, Marsdenia zehntneri, Matelea endressiae, M. ganglinosa, M. harleyi, M. morilloana, M. orthosioides, 'Metastelma' giuliettianum, 'M.' harley, 'M.' myrtifolium, Minaria cordata, Nephradenia asparagoides, Oxypetalum harleyi, Schubertia grandiflora, $S$. morilloana, S. multiflora e Tassadia burchellii. A ocorrência de Marsdenia zehntneri, Matelea endressiae, M. harleyi, Schubertia grandiflora e Tassadia burchellii no Espinhaço precisa ser confirmada, pois são espécies características de caatinga e foram registradas em localidades limítrofes do Espinhaço.

Este levantamento aponta mais espécies nativas para as quatro regiões do Espinhaço de Minas: no Sul, passando de 57 para 60 espécies; na Serra do Cipó, de 52 para 60; no Planalto de Diamantina, de 52 para 58; e no Norte, de 34 para 40. Com exceção da região Sul, que teve $D$. myrtilloides corrigida para $D$. leonii, a quantidade de espécies endêmicas do Espinhaço também aumentou nessas regiões. No Sul, diminuiu de 9 para 8, porém na Serra do Cipó, aumentou de 19 para 20, no Planalto de Diamantina, de 18 para 20, e no Norte, de 7 para 9. No núcleo do Espinhaço de Minas, a Serra do Cipó e o Planalto de Diamantina apresentam as taxas mais elevadas de endemismos, com praticamente um terço da flora de Asclepiadoideae endêmica do Espinhaço, cada qual com oito (ca. 15\%) espécies microendêmicas (restritas à região). Essas proporções são menores no Norte ( $c a$. $20 \%$ de espécies endêmicas do Espinhaço e 7\% de microendemismos) e no Sul (ca. $15 \%$ e $5 \%$, respectivamente). No Espinhaço da Bahia, a Chapada Diamantina possui diversidade e taxa de endemismos comparáveis às observadas na porção mineira: 59 espécies, sendo 10 (17\%) endêmicas e cinco (8\%) microendêmicas; o mesmo não acontece com as outras duas regiões. O Sul do Espinhaço da Bahia é o menos representativo em número de espécies (18) e apenas Barjonia chloraeifolia e Matelea morilloana são endêmicas do Espinhaço, enquanto a porção Norte do Espinhaço possui 32 espécies e apenas Metastelma myrtifolium é endêmica do Espinhaço (Fig. 3).

Ao todo, são reconhecidas 43 espécies endêmicas do Espinhaço: Minaria (com 13 espécies endêmicas), Ditassa (12), Hemipogon (7), Oxypetalum (4), Metastelma (3) e Barjonia (2), além de Cynanchum morrenioides e Matelea morilloana; incluindo cerca de $30 \%$ das Asclepiadoideae raras do país (Rapini et al. 2009). Apesar da distribuição de algumas espécies ter sido ampliada em relação àquela apontada na FEM, apenas Oxypetalum erostre perdeu os status de endêmica; a espécie foi acrescentada ao Norte do Espinhaço de Minas e também foi encontrada fora da Cadeia. Por outro lado, Minaria campanuliflora, descrita recentemente, foi adicionada entre as espécies microendêmicas, sendo exclusiva de São Gonçalo do Rio Preto, no nordeste do Planalto de Diamantina. A contribuição em termos de endemismos da porção baiana 'Barjonia' harleyi, 'Cynanchum' morrenioides, 'Metastelma' giuliettianum, 'M.' harleyi, 'M.' myrtifolium e 'Hemipogon' harleyi -, concentrada na região da Chapada Diamantina, é compatível à sua contribuição em termos de diversidade geral, mantendo o índice de endemismos no Espinhaço em torno de $30 \%$.

Progressos na sistemática das Asclepiadoideae do Espinhaço e implicações para a compreensão de sua diversidade

A FEM (Rapini 2000, Rapini et al. 2001) trouxe 21 novidades taxonômicas; mais de um quinto dos nomes ali apresentados eram inéditos, demonstrando uma mudança na perspectiva adotada para a classificação do grupo. Neste levantamento, temos uma quantidade considerável de mudanças taxonômicas em relação àquele tratamento; em menos de 10 anos, 26 ( $c$ a. 25\%) espécies da FEM tiveram sua classificação alterada ou corrigida e a posição de pelo menos 12 espécies (quase 10\% desta lista do Espinhaço) já se mostra inadequada, embora não haja ainda uma classificação alternativa disponível para a maioria delas. Se 'estabilidade taxonômica é ignorância' (Dominguez \& Wheeler 1997, aqui traduzido), fica evidente que o estudo das Asclepiadoideae do Espinhaço oferece um ótimo exemplo dos avanços pelos quais a sistemática de Asclepiadoideae vem passando nos últimos anos.

Até a década de 1930, as novidades taxonômicas em Asclepiadoideae estiveram relacionadas principalmente a descrições de espécies. A partir daquela década e associada à implantação do tipo na nomenclatura botânica, essa atividade passou a ser compensada pelo aumento significativo na detecção de sinônimos, praticamente estabilizando o número de espécies (Rapini et al. 2005). Nos últimos anos, a popularização

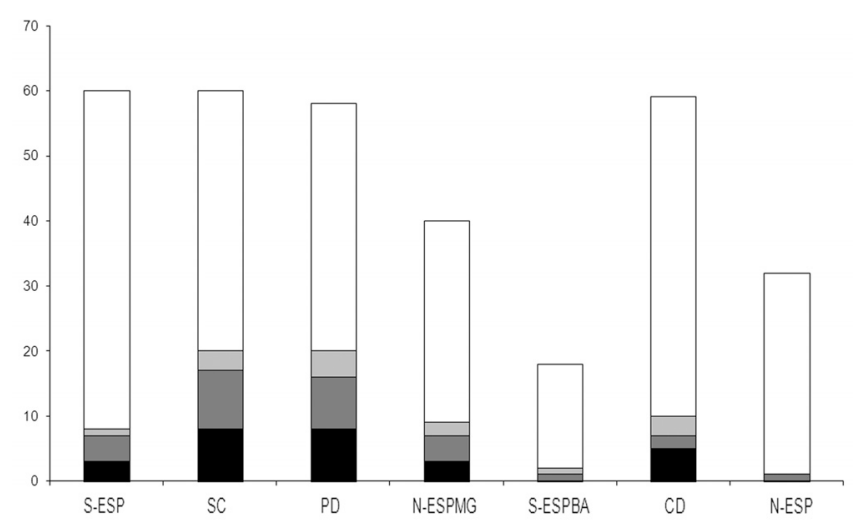

Fig. 3. Comparação do número de espécies de Asclepiadoideae entre as regiões da Cadeia do Espinhaço, indicando o número de espécies microendêmicas (restrita àquela região; em preto), endêmicas de uma das porções do Espinhaço (Minas Gerais ou Bahia, ocorrendo em mais de uma das regiões; em cinza-escuro) e endêmicas da Cadeia (ocorrendo em Minas Gerais e Bahia; em cinza-claro). S-ESP = Sul do Espinhaço; $\mathrm{SC}=$ Serra do Cipó; PD = Planalto de Diamantina; $\mathrm{N}-\mathrm{ESPMG}=$ Norte do Espinhaço de Minas Gerais; S-ESPBA $=$ Sul do Espinhaço da Bahia; $\mathrm{CD}=$ Chapada Diamantina; $\mathrm{N}-\mathrm{ESP}=$ Norte do Espinhaço. 
da sistemática filogenética tem canalizado as mudanças taxonômicas em direção a uma classificação que reflita de maneira mais precisa diferentes níveis de ancestralidade. A busca de uma maior compreensão das relações históricas em Asclepiadoideae passou a ser fundamental para a detecção de linhagens que possivelmente tiveram sua diversificação confinada ao Espinhaço. Essa mudança tem permitido uma percepção distinta daquela apresentada de maneira pictórica para o Espinhaço de Minas (Rapini et al. 2001), onde esses endemismos foram examinados de maneira dispersa, no nível de espécies e sem conotação histórica evidente (Rapini et al. 2002).

A desigualdade histórica no esforço amostral ao longo do Espinhaço pode confundir avaliações comparativas entre as regiões do Espinhaço (Rapini et al. 2002). Ainda assim, há atualmente mais dados florísticos e informações filogenéticas mais confiáveis do que há alguns anos, possibilitando que cenários evolutivos capazes de explicar a diversidade dos campos rupestres no Espinhaço sejam criados com mais precisão. A relação entre diversidade e taxas de endemismos notada entre as regiões do Espinhaço sugere que grande parte das espécies encontrada nessas serras tenha sido gerada in loco, o que está associado à diversificação de linhagens praticamente restritas ao Espinhaço (Queiroz et al. 2009). Nesse aspecto, merecem destaque as linhagens de Minaria (incluindo Barjonia harleyi e Hemipogon harleyi, ambas confinadas à Chapada Diamantina) e de Hemipogon do Espinhaço (excluindo $H$. acerosus, H. irwinii Fontella \& Paixão, H. setaceus Decne. e H. sprucei E.Fourn.), que concentram grande parte de sua diversidade $(70 \%$ e $85 \%$ das espécies, respectivamente) no Espinhaço, apontando para irradiações evolutivas dessas linhagens na Cadeia, em ambos os casos acompanhadas de uma diversificação maior na porção mineira.

Apesar da taxa de diversificação aparentemente ter sido maior no Espinhaço de Minas, é na porção baiana que encontramos os exemplos mais marcantes de disparates morfológicos, o que explicaria a posição incorreta e, em muitos casos, ainda incerta de suas seis espécies endêmicas. 'Cynanchum' morrenioides, por exemplo, continua designado a um gênero de Cynanchinae, apesar de pertencer a Orthosiinae, uma subtribo distante filogeneticamente (Liede-Schumann et al. 2005). A posição das espécies de 'Metastelma' do Espinhaço e a relação delas com as demais espécies de Metastelmatinae continuam discutíveis. Estudos filogenéticos com dados de plastídio mostram que elas estão mais relacionadas às espécies de Ditassa, como $D$. retusa, $D$. burchellii e D. hispida, enquanto a diversidade de Metastelma s.str. estaria centrada nas espécies do Caribe, América Central e norte da América do Sul (Liede-Schumann \& Meve 2004). Os dados nucleares, por sua vez, apontam relações diferentes, e uma definição sobre os limites de Metastelma e Ditassa permanece obscura (Silva 2010). Essas espécies continuam sendo tratadas em Metastelma exclusivamente por possuírem corona de lobos simples. Corona é um caráter extremamente lábil e sua utilização na definição de gêneros já foi criticada (e.g., Rapini 2002a), tendo sido desmistificada em estudos filogenéticos: Minaria, por exemplo, representa um clado altamente sustentando onde encontramos espécies com flores sem corona, espécies com flores de corona simples e espécies com flores de corona dupla (Konno et al. 2006, Rapini et al. 2006).

Em Minaria, encontramos, também, outro exemplo dessa divergência morfológica marcante em espécies endêmicas do Espinhaço da Bahia. Inicialmente, acreditou-se que todas as espécies desta linhagem estivessem representadas no Espinhaço, incluindo vários exemplos de microendemismos, então, exclusivamente na porção mineira. No entanto, sabese agora que 'Barjonia' harleyi e 'Hemipogon' harleyi, duas espécies endêmicas do Espinhaço da Bahia, também pertencem a esta linhagem (Silva 2008), formando possivelmente um clado (Silva 2010). A posição da primeira já havia sido aventada (Konno et al. 2006), mas a relação apontada para a segunda espécie é inusitada, já que 'Hemipogon' harleyi é completamente distinta morfologicamente das demais espécies de Minaria, tanto em relação ao hábito quanto em relação às estruturas florais. Por ter o apêndice do ginostégio rostrado, ela foi originalmente descrita em Melinia Decne. (Fontella-Pereira 1994), gênero atualmente considerado sinônimo de Philibertia Kunth (Goyder 2004) e que pertence a outra subtribo, Oxypetalinae. Foi transferida para Hemipogon (Goyder 2004) principalmente devido às folhas estreitas e o hábito volúvel, e sua afinidade com as espécies de Minaria dificilmente seria inferida não fosse a aplicação de dados moleculares para a reconstrução filogenética de Metastelmatinae (Silva 2008, 2010).

Os resultados filogenéticos obtidos em Asclepiadoideae, especialmente em Metastelmatinae (Silva 2010), ainda são insuficientes para a elaboração de inferências detalhadas sobre o processo de diversificação no Espinhaço. A dificuldade para se estabelecer uma estrutura hierárquica consistente para a filogenia da subfamília, principalmente nesta subtribo, parece estar intimamente associada a uma irradiação rápida e relativamente antiga da linhagem. Este padrão de diversificação explicaria a grande quantidade de homoplasias morfológicas e moleculares e a incongruência entre diferentes fontes de dados. Mesmo um grande número de regiões plastídiais (trn $\mathrm{T}-\mathrm{F}, r p s 16, t r n \mathrm{~S}-\mathrm{G}, m a t \mathrm{~K}, p s b \mathrm{~A}$ e $\operatorname{trn} \mathrm{E}-\mathrm{Y}$ ) foram insuficientes para a resolução dos nós basais da subtribo, a exceção do clado composto por Blepharodon lineare e $B$. ampliflorum, que desponta como grupo-irmão do restante da subtribo (Rapini et al. 2006). A falta de resolução para esses nós pode estar diretamente relacionada à desproporcionalidade entre os comprimentos de ramo da árvore, gerada por eventos de diversificação rápida (internós basais curtos) seguidos de longos períodos de divergência (ramos derivados longos). Como resultado, as várias homoplasias produzidas durante a divergência acabariam por obscurecer as poucas sinapomorfias produzidas durante a irradiação do grupo (Rokas \& Carroll 2006), dificultando a resolução entre os grandes grupos de Metastelmatinae. Uma irradiação rápida favoreceria também que parálogos 
heteromórficos no ancestral permanecessem durante a diversificação inicial da subfamília, sendo posteriormente fixados de maneira aleatória entre as linhagens. Nesses casos, a filogenia do alelo pode não corresponder à filogenia dos organismos (Whitfield \& Lockhart 2007), o que explicaria a incongruência entre os resultados obtidos a partir de de dados nucleares (ITS) e plastidiais.

Apesar das dificuldades encontradas para se reconstruir a filogenia de Metastelmatinae, a ampliação do conhecimento sobre a diversidade das Asclepiadoideae do Espinhaço e sobre a distribuição geográfica de suas espécies, associada à detecção de linhagens crípticas, como as formadas por Minaria e pelas espécies de Hemipogon do Espinhaço, sugerem que várias das espécies endêmicas do Espinhaço devem estar proximamente relacionadas, formando linhagens que teriam surgido e se diferenciado no próprio Espinhaço. Por outro lado, a maneira como essa evolução aconteceu nas porções de Minas e da Bahia não parece ter sido semelhante. Em Asclepiadoideae, podemos observar divergências morfológicas tanto entre as espécies de Minas como entre as da Bahia, denotando processos de anagênese compátiveis nas duas porções do Espinhaço; a diversidade em número de espécies, no entanto, é bem maior em Minas do que na Bahia. Duas hipóteses poderiam explicar este padrão: na Bahia, a anagênese não teria sido acompanhada com a mesma freqüência por eventos de cladogênese, o que explicaria a menor diversidade de Asclepiadoideae em número de espécies nessa porção; ou, alternativamente, a flora de Asclepiadoideae estaria mais suscetível a eventos de extinção na porção baiana, gerando linhagens relativamente depauperadas, o que explicaria o menor número de espécies e a maior descontinuidade morfológica entre elas. Qualquer das alternativas, no entanto, parece apontar para diferenças ambientais (e.g., a maior fragmentação nas regiões nucleares de Minas ou maior aridez na porção baiana, respectivamente) como as principais responsáveis pela alta diversidade e elevadas taxas de endemismos na Cadeia do Espinhaço.

\section{Agradecimentos}

Este estudo faz parte do material apresentado para promoção na carreira de Titular B para Pleno na Universidade Estadual de Feira de Santana. Os dados adicionados após 2000 puderam ser acumulados graças ao apoio de várias pessoas: os curadores e técnicos de todos os herbários, invariavelmente têm me recebido de maneira extremamente atenciosa e cordial; merece destaque também, o pessoal que tem me apoiado e inspirado ininterruptamente desde a graduação: os Drs Renato de Mello-Silva e Maria Lúcia Kawasaki, que continuam a me orientar (mais esporadicamente, é verdade!) e os Drs. Pirani e Ana Maria Giulietti, que, de perto ou de longe, também estão sempre me acompanhando; os Drs Abel A. Conceição, Luciano Paganucci de Queiroz e Cássio van den Berg, com quem tenho aprendido muito sobre o Espinhaço desde que cheguei à UEFS, e aos estudantes do PPG-Bot, especialmente minhas orientadas Patrícia L. Ribeiro e Uiara Catharina Soares e Silva, que estão trabalhando diretamente com as Asclepiadoideae do Espinhaço; os especialistas em Asclepiadoideae, especialmente o Dr. Fontella-Pereira, com quem tenho debatido desde o início dos meus estudos e cuja experiência e contribuição para a taxonomia do grupo são admiráveis, e a Dra. Maria Ana Farinaccio (e outro revisor 'anônimo') pela revisão do Ms. Desde 2001, os estudos em Asclepiadoideae contaram com uma bolsa da KLARF (2001-2002), receberam suporte do Instituto do Milênio do Semi-árido (IMSEAR; CNPq) e do Programa de Pesquisa em Biodiversidade (PPBio) do Semi-árido (MCT) para a realização de coletas, e, atualmente, estão sendo financiados pela FAPESB, dentro do projeto em filogenia e diversidade de Apocynaceae do Brasil, e incetivados pelo CNPq (bolsa PQ2).

\section{Referências}

BARBOSA, W.A. 1995. Dicionário histórico geográfico de Minas Gerais. Ed. Itatiaia. Rio de Janeiro.

DOMINGUEZ, E. \& WHEELER, Q.D. 1997. Taxonomic stability is ignorance. Cladistic 13: 367-372.

FARINACCIO, M.A. 2007. Sistemática molecular de Oxypetalum R.Br. (Apocynaceae, Asclpeiadoideae). Tese de Doutorado. Universidade de São Paulo. São Paulo.

FARINACCIO, M.A. \& MELLO-SILVA, R. 2004. Asclepiadoideae (Apocynaceae) do Parque Nacional da Serra da Canastra, Minas Gerais, Brasil. Bol. Bot. Univ. São Paulo 22: 53-92.

FONTELLA-PEREIRA, J. 1994. Estudos em Asclepiadaceae, XXVIII. Duas espécies novas da Bahia, Brasil. Pabstia 5(1): 1-3.

FONTELLA-PEREIRA, J. (coord.) 2005. Asclepiadaceae. In M.G.L. Wanderley, G.J. Shepherd, T.S. Melhem \& A.M. Giulietti (eds) Flora fanerogâmica do Estado de São Paulo. FAPESP, RiMa. São Paulo, vol. 4, p. 93-156.

FONTELLA-PEREIRA, J. \& FERREIRA, M.V. 2005. O gênero Macroditassa (Apocynaceae-Asclepiadoideae) no Brasil. Bonplandia 14: 7-34.

FONTELLA-PEREIRA, J. \& KONNO, T.U.P. 2001. Asclepiadaceae. In A.F. Costa \& I.C. Dias (orgs) Flora do Parque Nacional da Restinga de Jurubatiba e arredores, Rio de Janeiro, Brasil: listagem florística e fitogeografia. Museu Nacional do Rio de Janeiro. Rio de Janeiro, p. 34-36.

FONTELLA-PEREIRA, J., VALENTE, M.C. \& SCHWARZ, E.A. 1984. Contribuição ao estudo das Asclepiadaceae brasileiras, XXI. Asclepiadaceae do município de Ouro Preto, Estado de Minas Gerais - uma sinopse. Bol. Mus. Bot. Kuhlmann 7(2): 63-127.

FONTELLA-PEREIRA, J., VALENTE, M.C. \& MARQUETE, N.F.S. 1995. Flora da Serra do Cipó, Minas Gerais: Asclepiadaceae. Bol. Bot. Univ. São Paulo 14: 131-179.

FONTELLA-PEREIRA, J., SANTOS, L.B., FERREIRA, M.V., GOES, M.B. CARVALHO, R.J.P., KONNO, T.U.P. \& MEZABARBA, V.P. 2003. Asclepiadaceae. In T.B. Cavalcanti \& A.E. Ramos (orgs) Flora do Distrito Federal, Brasil. EMBRAPA Recursos Genéticos e Biotecnologia 3: 65-123. 
FONTELLA-PEREIRA, J., VALENTE, M.C., MARQUETE, N.F.S. \& ICHASO, C.L.F. 2004. Apocináceas-Asclepiadóideas. Flora ilustrada catarinense. Herbário Barbosa Rodrigues. Itajaí.

GOYDER, D.J. 1995. Asclepiadaceae. In B.L. Stannard (ed.) Flora of the Pico das Almas, Chapada Diamantina, Bahia. Royal Botanic Gardens. Kew, p. 140-150.

GOYDER, D.J. 2003. A synopsis of Morrenia Lindl. (Apocynaceae subfam. Asclepiadoideae). Kew Bull. 58: 713-721.

GOYDER, D.J. 2004. An amplified concept of Philibertia Kunth (Apocynaceae: Asclepiadoideae), with a synopsis of the genus. Kew Bull. 59: 415-451.

GOYDER, D.J. \& NICHOLAS, A. 2001. A revision of Gomphocarpus R. Br. (Apocynaceae: Asclepiadeae). Kew Bull. 56: 769-836.

GOYDER, D.J., NICHOLAS, A. \& LIEDE-SCHUMANN, S. 2007. Phylogenetic relationships in subtribe Asclepiadinae (Apocynaceae: Asclepiadoideae). Ann. Missouri Bot. Gard. 94: 423-434.

GUEDES, M.L.S. \& ORGE, M.D.R. 1998. Check-list das espécies vasculares do Morro do Pai Inácio (Palmeiras) e da Serra da Chapadinha (Lençóis), Chapada Diamantina, Bahia, Brasil. Universidade Federal da Bahia. Salvador.

HARLEY, R.M. \& SIMMONS, N.A. 1986. Florula of Mucugê, Chapada Diamantina - Bahia, Brazil. Royal Botanic Gardens. Kew.

KOCH, I., SIMÕES, A.O., RAPINI, A. \& FONTELLA-PEREIRA, J. 2009. Apocynaceae. In J.R. Stehmann, R.C. Forzza, A. Salino, M. Sobral, D.P. Costa \& L.H.Y. Kamino (eds) Plantas da floresta atlântica. Jardim Botânico do Rio de Janeiro. Rio de Janeiro, p. 132140.

KONNO, T.U.P. 2005. Ditassa R.Br. no Brasil (Asclepiadoideae Apocynaceae). Tese de Doutorado. Universidade de São Paulo. São Paulo.

KONNO, T.U.P., FONTELLA-PEREIRA, J. \& ARAUJO, D.S.D. 2001. Asclepiadaceae brasilienses, XII. Diversity and distribution of taxa from the sandy coastal - plan vegetation of Rio de Janeiro. Asklepios 82: 11-18.

KONNO, T.U.P., RAPINI, A., GOYDER, D.J. \& CHASE, M.W. 2006. The new genus Minaria (Apocynaceae). Taxon 55: 421-430.

KRINGS, A., THOMAS, D.T. \& XIANG, Q.-Y. 2008. On the generic circumscription of Gonolobus (Apocynaceae, Asclepiadoideae): evidence from molecules and morphology. Syst. Bot. 33: 403415.

LIEDE, S. \& MEVE, U. 2004. Revision of Metastelma (ApocynaceaeAsclepiadoideae) in southwestern North America and Central America. Ann. Missouri Bot. Gard. 91: 31-86

LIEDE, S. \& KUNZE, H. 2002. Cynanchum and the Cynanchinae (Apocynaceae-Asclepiadoideae) - A molecular, anatomical and latex triterpenoid study. Org. Divers. Evol. 2: 239-269.

LIEDE, S. \& TAÜBER, A. 2002. Circumscription of the genus Cynanchum (Apocynaceae-Asclepiadoideae). Syst. Bot. 27: 789801.

LIEDE-SCHUMANN \& MEVE, U. 2008. Nomenclatural novelties and one new species in Orthosia (Apocynaceae, Asclepiadoideae). Novon 18: 202-210.

LIEDE-SCHUMANN, S., RAPINI, A., GOYDER, D.J. \& CHASE, M.W. 2005. Phylogenetics of the New World subtribes of Asclepiadeae (Apocynaceae-Asclepiadoideae): Metastelmatinae, Oxypetalinae, and Gonolobinae. Syst. Bot. 30: 183-194.
MARQUETE, N.F.S., FONTELLA-PEREIRA, J. \& VALENTE, M.C. 2007. Asclepiadoideae (Apocynaceae) from southeastern Brazil. I. The genus Oxypetalum from Rio de Janeiro State, Brazil. Ann. Missouri Bot. Gard. 94: 435-462.

MEZABARBA, V.P., GOES, M.B., RAPINI, A., KONNO, T.U.P., FONTELLA-PEREIRA, J. \& GOYDER, D.J. 2006. In C.F.L. Gamarra-Rojas, A.C. Mesquita, S. Mayo, C. Sother, M.R.V. Barbosa, \& E. Dalcin (eds) Checklist das Plantas do Nordeste. Ministério de Ciências de Tecnologia. Brasília, p. 17-20; CNIP, Recife. (versão 1.5): http://www.cnip.org.br/bdpn/index.php.

MONGUILHOTT, L. \& MELLO-SILVA, R. 2008. Apocynaceae do Parque Estadual de Ibitipoca, Minas Gerais, Brasil. Bol. Bot. Univ. São Paulo 26: 93-130

MURPHY, H. 1986 A revision of the genus Fischeria (Asclepiadaceae). Syst. Bot. 11:229-241.

QUEIROZ, L.P., SANTOS, A.K.A., CARNEIRO, D.S., SOUZA, É.R., CONCEIÇÃO, A.S., SIMON, M.F., MACHADO, M.C., ANDRADE, M.J.G., GIULIETTI, A.M., RAPINI, A., BERG C. \& CONCEIÇÃO, A.A. 2009. Por que há tantas espécies raras nos campos rupestres da Cadeia do Espinhaço? - o que as filogenias podem nos responder. Botânica brasileira: futuro $e$ compromissos. $60^{\circ}$ Congresso Nacional de Botânica, 2009. Feira de Santana.

RAPINI, A. 2000a. Sistemática: Estudos em Asclepiadoideae (Apocynaceae) da Cadeia do Espinhaço de Minas Gerais. Tese de Doutorado. Universidade de São Paulo. São Paulo. http://www. teses.usp.br/teses/disponiveis/41/41132/tde-12122001-085018/

RAPINI, A. 2000b. Combinação em Macroditassa Malme (Apocynaceae, Asclepiadoideae). Bradea 8(32): 201.

RAPINI, A. 2002a. Six new species of Ditassa R. Br. from the Espinhaço Range, Brazil, with notes on generic delimitation in Metastelmatinae (Apocynaceae - Asclepiadoideae). Kew Bull. 57: 533-546.

RAPINI, A. 2002b. Oxypetalum rusticum (Apocynaceae, Asclepiadoideae), a new species from the Espinhaço Range of Minas Gerais, Brazil. Novon. 12: 385-387.

RAPINI, A. 2003. Nomenclatural notes in Asclepiadoideae (Apocynaceae): publication of some previously invalidly published names. Bol. Bot. Univ. São Paulo 22: 277-278.

RAPINI, A. 2006. Apocynaceae. In A.M. Giulietti, A.A. Conceição \& L.P. Queiroz (eds) Diversidade e caracterização das fanerógamas do Semi-árido brasileiro. Instituto do Milênio do Semi-árido (A.M. Giulietti \& L.P. Queiroz, eds). Ministério de Ciências e Tecnologia. Brasília, vol. 1, p. 47-52.

RAPINI, A. 2010. Asclepiadoideae (Apocynaceae). Espinhaço Range, Minas Gerais and Bahia, Brazil. In R. Forster, J. Phillip \& T. Wachter (orgs) Rapid color guide \#19 version 2. Environment and Conservation Programs. Field Museum. Chicago, disponível em: http://fm2.fieldmuseum.org/plantguides/guideimages.asp?ID=157 (acesso em 3 de agosto de 2010).

RAPINI, A., MELLO-SILVA, R. \& KAWASAKI, M.L. 2001. Asclepiadoideae (Apocynaceae) da Cadeia do Espinhaço de Minas Gerais, Brasil. Bol. Bot. Univ. São Paulo 19: 55-169.

RAPINI, A., MELLO-SILVA, R. \& KAWASAKI, M. L. 2002. Richness and endemism in Asclepiadoideae (Apocynaceae) from the Espinhaço Range of Minas Gerais, Brazil - a conservationist view. Biodivers. Conserv. 11: 1733-1746. 
RAPINI, A., MELLO-SILVA, R. \& KAWASAKI, M.L. 2003a. Flora de Grão-Mogol: Apocynaceae II (Asclepiadoideae). Bol. Bot. Univ. São Paulo 21: 83-96.

RAPINI, A., CHASE M.W., GOYDER, D.J. \& GRIFFITHS, J. 2003 b. Asclepiadeae classification: evaluating the phylogenetic relationships of New World Asclepiadoideae (Apocynaceae). Taxon 52: 33-50.

RAPINI, A., FONTELLA-PEREIRA, J., LAMARE, E. \& LIEDESCHUMANN, S. 2004. Taxonomy of Peplonia (including Gonioanthela) and a reinterpretation of Orthosieae (Asclepiadoideae, Apocynaceae). Kew Bull. 59: 531-539.

RAPINI, A., GOYDER, D.J., KONNO, T.U.P. \& FARINACCIO, M.A. 2005. Progress in asclepiad taxonomy: species number in Brazilian Asclepiadoideae (Apocynaceae) through time. Kew Bull. 60: 111-115.

RAPINI, A., KONNO T.U.P. \& CHASE M.W. 2006. Phylogenetics of South American Asclepiadoideae (Apocynaceae). Taxon 55: 119-124.

RAPINI, A., BERG, C. \& LIEDE-SCHUMANN, S. 2007. Diversification of Asclepiadoideae (Apocynaceae) in the New World. Ann. Missouri Bot. Gard. 94: 407-422.

RAPINI, A., RIBEIRO, P.L., LAMBERT, S. \& PIRANI, J.R. 2008. A flora dos campos rupestres da Cadeia do Espinhaço. Megadiversidade 4: 16-24.

RAPINI, A., SOUZA-SILVA, R.F. \& SAMPAIO, L.N.P. 2009. Apocynaceae. In A.M. Giulietti, A. Rapini, M.J.G. Andrade, L.P. Queiroz \& J.M.C. Silva (orgs) Plantas raras do Brasil. Conservação Internacional do Brasil \& Universidade Estadual de Feira de Santana, Belo Horizonte, p. 54-64.

RAPINI, A., KOCH, I., KINOSHITA, L.S., SIMÕES, A.O., SPINA, A.P. 2010a. Apocynaceae. In Lista de espécies da Flora do Brasil. Jardim Botânico do Rio de Janeiro. Rio de Janeiro, Disponível em http://floradobrasil.jbrj.gov. br/2010/FB000048 (acesso em 3 de agosto de 2010).
RAPINI, A., RIBEIRO, P.L. \& SILVA, U.C.S. 2010b. 667. Hemipogon abietoides. Curtis's Bot. Mag. 27: 1-13.

ROCKAS, A. \& CARROL, S.B. Bushes in the tree of life. PLoS Biol. 4(11): e352. DOI: 10.1371/journal.pbio.0040352.

SCHWARZ, E.A. 2003. O gênero Oxypetalum R.Br. (Apocynaceae, Asclepiadoideae) no Estado do Paraná. Tese de Doutorado. Universidade Estadual Paulista. Rio Claro.

SILVA, U.C.S. 2008. Sistemática molecular de Metastelmatinae (Asclepiadoideae, Apocynaceae) com ênfase em cinco espécies endêmicas da Chapada Diamantina, Bahia. Monografia de Conclusão do Curso de Ciências Biológicas. Universidade Estadual de Feira de Santana. Feira de Santana.

SILVA, U.C.S. 2010. Estudos filogenéticos moleculares em Metastelmatinae (Asclepiadoideae, Apocynaceae). Dissertação de Mestrado. Universidade Estadual de Feira de Santana. Feira de Santana.

SILVEIRA, A. 1908. Flora e serras mineiras. Imprensa official. Belo Horizonte.

STANNARD, B.L. (ed.). 1995. Flora of the Pico das Almas, Chapada Diamantina, Bahia. Royal Botanic Gardens. Kew.

WHITFIELD, J.B. \& LOCKHART, P.J. 2007. Deciphering ancient radiations. Trends. Ecol. Evol. 22: 258-265.

WOODSON, R.E. 1954. The North American species of Asclepias L. Ann. Missouri Bot. Gard. 41: 1-211.

ZAPPI, D.C., LUCAS, E., STANNARD, B.L., NIC DE LUGHADHA, E., PIRANI, J.R., QUEIROZ, L.P., ATKINS, S., HIND, D.J.N., GIULIETTI, A.M., HARLEY, R.M. \& CARVALHO, A.M. 2003. Lista das plantas vasculares de Catolés, Chapada Diamantina, Bahia, Brasil. Bol. Bot. Univ. São Paulo 21: 345-398. 